\title{
Friedrich Wilhelm NIETZSCHE
}

\section{Autosuperación del Hombre}





\section{Ricardo Torres Medrano}

\section{Friedrich Wilhelm NIETZSCHE}

Autosuperación del Hombre

Dei Genitrix 
Diseño de Tapa:

Cecilia Ferrantino - puntocdesign@gmail.com

Correción: Fernanda Mercerat

Impresión: Imprenta Servicop, 50 N 742. La Plata, Bs. As. - Argentina.

www.imprenta servicop.com.ar

Torres Medrano, Ricardo

Friedrich Wilhelm Nietzsche : autosuperación del Hombre . - 1a ed. - La Plata: Dei Genitrix, 2012.

127 p.; $15 \times 21 \mathrm{~cm}$.

ISBN 978-987-9014-88-2

1. Filosofía Moderna. I. Título.

CDD 190

DEI GENITRIX: Órgano Editor sin fines de lucro

Del Instituto Literario Horacio Rega Molina de la República Argentina. Tomo 106.

Calle 42 N$^{\circ} 621$ B1904AGY La Plata - (0221) 4823558

Domicilio Postal: C.C. 705 B1900WAA La Plata (Argentina)

(C) 2012

(C) Dei Genitrix

Primera Edición

Obra: Friedrich Wilhelm NIETZSCHE: Autosuperación del Hombre

E-mail: torresmedrano@speedy.com.ar

Made and printed in Argentina

Hecho e impreso en la República Argentina

ISBN 978-987-9014-88-2

Hecho el depósito que previene la Ley 11.723

Prohibida la reproducción total o parcial de este libro, o su almacenamiento en un sistema informático, su transmisión por cualquier medio electrónico, mecánico, fotocopia, registro u otros medios sin el permiso previo por escrito de los titulares del copyright.

Todos los derechos de esta edición reservados por Dei Genitrix.

La Plata, Buenos Aires. ARGENTINA.

Esta edición se terminó de imprimir en los talleres gráficos Imprenta Servicop

$50 \mathrm{~N}^{\mathrm{o}}$ 742, La Plata, Bs. As. - Argentina, durante el mes de Julio de 2012. 


\begin{abstract}
Dedico estas líneas a Arturo Benedicto Quevedo, el infalible y espontáneo amigo en tiempos espinosos, el confidente que buscaba certezas, el guía esclarecedor de riguroso traje azul o simplemente "el Tío", como le decíamos sus sobrinos (Marta Medrano, Enrique Boccolini y Horacio Tucci, entre otros). Y mi persistente recuerdo de él: la generosa sonrisa, la intranquila mirada en lo distante, el vaso de cristal con whisky importado en una mano, el cigarrillo en la otra y agudamente atento a escuchar la respuesta cuando me preguntaba qué clase de vuelo pretendía alcanzar: ¿el de perdiz, o el de cóndor quizás?
\end{abstract}

In memoriam 



\section{Epítome Nietzscheano}

(Sobre un tal Friedrich Wilhelm y lo que dejó)

O más bien, recensión de esta obra titulada FRIEDRICH WILHELM NIETZSCHE: Autosuperación del Hombre de Ricardo Torres Medrano, filósofo en fin, y por principio, y desde su inicio, lo que yo no soy; aunque... todo hombre que piensa en sí, para poder acceder al "noscete ipsum” (sabiamente Don Quijote dijo "Yo sé quién soy", Primera Parte, Cap. V; y también, sabiamente, le dijo a Sancho: "has de poner los ojos en quien eres, procurando conocerte a ti mismo, que es e l más difícil conocimiento que puede imaginarse", Segunda Parte, Cap. XLII), es porque reflexiona sobre los no pocos "por qués", avizorando anticipadamente que, por ello, deben existir respuestas (dentro o fuera de él).

$\mathrm{Y}$ con esa acendrada inquietud de curioso (e impertinente), más que de (serio) investigador, en más de una ocasión, y alternando con las respuestas de la literatura (en especial las de la poesía), 
pasaron por mí las de la Filosofía en general (amén de ciertas "especies" de ella, si es que son tales, como la Ontología, Ética, Estética, Metafísica, etc., y además, de otras aplicadas al Derecho, la Sociología o la Política).

Y así, ante esta "monumental" obra de Torres Medrano (porque "monumental" es la de Nietzsche), me encuentro avocado a este epítome o recensión de la misma, sin otra alternativa, sin grado, título o diploma que no fuese sino el de la magistratura de la cátedra científica, que no poseo, aunque sí la modesta vocación de un artesano de la cultura o de las Humanidades; y así, repito, voy sin prisa y sin pausa, luego de las dos sostenidas lecturas del aludido texto, para puntualizar algunos aspectos de é1, sin otra intención que la de intentar un mero discurso lo más claro, preciso y escueto de este magno y extenso horizonte nietzscheano en la perspectiva de la ilustre pluma de Torres Medrano, quien se ve favorecido en el doble dominio de la Filosofía y del idioma Alemán.

$\mathrm{Y}$ en este primer tramo no puedo dejar sino el testimonio de algunas lejanas lecturas efectuadas de unos pocos textos del filósofo alemán, además de las densas conferencias sobre el mismo de Narciso Pousa, a las que asistí con deleite espiritual y provecho humanístico, así como los recordados diálogos con Emilio Estiú, o las clases de Metafísica en Humanidades de Mons. Octavio Nicolás Derisi, etc.

\section{II}

No sé lo que acaece de momento sobre alguna circunstancia; pero esto viene a cuento (aunque anecdóticamente provocado) sobre una cierta Oda (que titulé a1 "Assiduus usus"), al advertir en cierta unidad académica (de la U.N.L.P.), en la que transcurrí como 
docente los últimos tres decenios de una jornada de más de media centuria. Lo cierto es que el tema central, o corazón del discurso poético, era la rutina (o los rutinarios de quienes estaban y egresaban, y seguirá siendo así, de la mentada unidad que debiendo tener el privilegio de lo teórico, desciende a cierto pragmatismo o practicidad que desemboca en la rutina. Decía en ella (la mentada Oda) lo que entonces dije (ver TORRES MEDRANO, Ricardo; EDUCACIÓN PÚBLICA UNIVERSITARIA. Visión estratégica en favor del desarrollo; La Plata; Dei Genitrix; 2012. Escolio, ps. 11-23) y cuanto a continuación añado conclusivamente (en otra Oda):

\section{Al Maestro ${ }^{1}$}

"Padre y maestro mágico, liróforo celeste", itero así en Darío. Y qué si no diría hoy por ti, maestro, denostado por los necios o envidiosos que no saben la verdad y ni la esencia de Patria, de nación y ni de Hispania, y de Argentina, más allá de Buenos Aires.

Hora de lealtad con nuestros padres, con Belgrano, Güemes, San Martín o Artigas, y tantos que murieron por nosotros, y otros padres, como tú, el más auténtico de Patria y de país, que te llora después de toda ausencia, y de sustitución.

Esos de la violeta y de la moda. Egregio y singular y benemérito en el más eminente paraninfo, ¡salud! 
Y por qué de todo esto (curiosamente "anecdótico"), si no y a propósito del ítem "Espíritu libre", donde Torres Medrano tiene oportunidad de anticiparse a mi Oda, de esta suerte (con Friedrich Wilhelm): "Igualmente, lo más importante en la naturaleza del espíritu libre no reside en tener opiniones justas, sino en haberse desligado de lo convencional; de esta manera, lleva en sí mismo el "espiritu de la investigación de la verdad" ya que "...él exige razones, los otros, creencias". Al final, el espíritu libre abriga la verdad y haber vivido en el error es para él un beneficioso recuerdo; los espíritus cautivos en cambio proclaman el error y haber muerto por la verdad será para ellos sólo una vaporosa y narcóticamente opiácea ilusión. De todos modos aquél es muy débil, especialmente en la acción pues conoce muchísimos motivos y criterios; mientras que éstos no necesitan razonar su comportamiento pues su tradición y su moral prescriben su conducta y por lo tanto también su vida".

"Además, un espíritu libre no puede adoptar otro punto de vista con respecto al Cristianismo que no sea el crítico" (sic); quizá, como lo fue en un principio, por parte del Cristianismo... que si bien puede haber tenido, y tiene, al Judaísmo como el hermano mayor, (comenzando por el propio Moisés, autor del Pentateuco), todo el Antiguo Testamento sigue presenciando el panorama antiguo y moderno como tiempo de preparación, elegía de un pasado extenso que perdura en el Judaísmo y en el Protestantismo, además de los Testigos de Jehová, etc.; hasta tal punto que sigue brillando (per omia secula seculorun): Sanguinis mei novit et aeterni testamenti (Sangre de la alianza nueva y eterna).

¿Quiso, acaso, fundar una nueva religión o continuar la que estaba y está aggiornándola de algún modo, sin saber por qué? "Todo gran hombre posee una fuerza retroactiva, a partir de la cual puede revisar otra vez toda la Historia, descubrir secretos que aun guarda celosamente el pasado y reinterpretar nuevamente los relatos establecidos por la tradición"; mas, tal intento revisionista no pocas 
veces se ha dado en la ciencia histórica y aun en la Filosofía de la Historia. Aunque aquel "todo gran hombre", sin duda, "pertenece a una casta de individuos que sólo quieren 'llegar a ser lo que son', es decir, los nuevos (...), los próximos educadores" (sic).

\section{III}

Sin el ánimo desvirtuativo de los "períodos" (tres, que preceptúa el texto, sin descontar o desconocer el postrer "Ocaso"), es de observar el preciso esquema en que Torres Medrano acepta e1 desafío de la composición de $\boldsymbol{F}$.W.N.: Autosuperación del Hombre y el desarrollo didáctico de una esperanza, más que de un pasado impertérrito o inintimidable. Desde luego que el material de un experto en los campos de las genialidades (se compartan o no los postulados, las premisas y las conclusiones), sin embargo, no empece la voluntad del autor de este texto, así como la del autor alemán. Frente a cada postura, diagramación, tesitura o la perplejidad de los cantos o de los oráculos, aparece ese trazo seguro, en la inquietud y la reflexión, y la propuesta inclaudicable que no resigna nada, nada, nada, que no fuese la convincente postura del súper.

E1 lector, el estudioso, el inquieto habrá de tener ese espacio que solamente ciertos "grandes" lo ofrecen, no sólo porque lo conocen sino porque han degustado, con deleite y utilidad, las visiones que quienes vuelan bajo (si es que vuelan) nunca han querido, podido ni deseado conocer, ni menos saber. 


\section{IV}

Es probable que muchos compartan conmigo que, a través de esta "galería" propuesta y tramitada por Torres Medrano, se pueda o se logre advertir a un Friedrich Wilhelm nada lúgubre, poco negativo, apesadumbrado o pesimista. Ni siquiera a un superficial nihilista, o sea, la negación de todo, porque eso es imposible en una mente de alcance genial. Nihil obstat, a mi juicio, para reconocer la estatura filosófica de este alemán; y si bien puede advertirse su postura de abstracción tal de todo, sin embargo no puede reducirse a negar que él existe porque piensa. "Pienso... luego existo", soy.

Otra faceta digna de consideración a los fines de los estudios y las consabidas hermenéuticas, es la que concierne a lo dogmático, espacio donde el alemán se maneja con destreza y seguridad, no obstante suscribirse contra los dogmas; y sin centrarse en una contradictio in adjecto $^{2}$, despeja con habilidad la densa niebla que intentarían soplarle los desencantados obsecuentes de la superficialidad, pues el alemán es un consecuente de sí mismo y una alternativa para pensar en el Hombre, su vida, su drama, su mundo (aunque siga esperando con amor la reconciliación del Hombre consigo mismo).

La tentativa de analizar exhaustivamente el trabajo (monumental de Torres Medrano y del propio Friedrich Wilhelm), es pensar en lo excusado, pues en la meta final esa tentativa (que no haya sido desistida), podría pasar a ser frustrada.

He querido redactar estas modestas líneas, sin entrar en honduras (porque no soy filósofo), nada más ni nada menos que, en sentido de gratitud hacia el profesor Torres Medrano, quien tuvo la generosidad de reconocerme aplicado a respetar la tarea humanística; y además, en homenaje a los tres grandes que mencioné ab initio y a quienes tanto les sigo debiendo: Octavio Nicolás Derisi, Emilio Estiú y en especial a Narciso Pousa a quien alguna vez se le 
F.W. NIETZSCHE: Autosuperación del Hombre

consultó cuál era la finalidad en la búsqueda de (y amor a) la verdad, respondió sonriente que "es la de encontrar o descubrir el error"; y cuando se le preguntó qué era el filósofo, sonriente dijo: "vivir como tal".

Atilio Milanta

La Plata,

Febrero de 2012 



\section{Algunas motivaciones $\mathbf{y}$ gratitudes a la presente edición}

And what's untimely done; so haply slander-

Whose whisper o'er the world's diameter, As level as the cannon to his blank, Transports his pois'ned shot-may miss our name, And hit the woundless air. ${ }^{3}$

Este trabajo descansó apaciblemente mientras estuvo guardado en una carpeta por más de veinte años. Se le han cambiado algunas palabras y reestructurado algunos párrafos con el ánimo de clarificar la exposición de la obra del filósofo de Röcken, conservando el mismo espíritu y propósito original.

El pensamiento de Friedrich Wilhelm Nietzsche, sin duda y sencillamente el de un estricto educador del siglo XIX, es complejo y demoledor porque se basa en la destrucción de la cultura para construir una nueva a partir de sus cenizas. Es asimismo una reflexión crítica en la que todos los recursos son válidos y muchas voces suelen alzarse a favor y en contra con los atuendos de célebres defensores e ilustres detractores. En este sentido, algunas de las acusaciones más incisivas y lapidarias, sino las mayores, que reciben el cristianismo y todas sus ramificaciones posteriores tienen su origen en el pensamiento de Nietzsche. $\mathrm{Y}$ al margen de las diversas reinterpretaciones que se hacen acerca de su pensamiento, en 
especial a partir del surgimiento del nacionalsocialismo alemán, el propósito del presente trabajo consiste en llevar adelante una exposición que resulte ser lo más fiel posible a la obra del filósofo, independientemente de las consideraciones personales del autor de este libro. No obstante lo dicho, y valga como actitud recomendable tanto en la investigación filosófica y científica, como en la labor docente, no debería haber preocupación ante las críticas por duras o atinadas que pudieran ser sino, y por el contrario, ante la falta de esclarecedoras y originales respuestas frente a ellas.

En otro orden de cosas, quiero dar también las gracias a las siguientes autoridades y amigos a quienes menciono en orden alfabético para evitar la suspicacia acerca de fastidiosas predilecciones:

Prof. Silvia BUSETTO, quien con su riguroso y preciso análisis sugirió la traducción más apropiada sin traicionar el espíritu original de las citas de William Shakespeare;

Dr. Diego CAMPORA, María Mercedes DUARTE, Andrea y Daniela, quienes contribuyeron con libros inspiradores;

Arq. Martín COMMESSATTI, por su ingenua madurez;

Dr. Juan CONSTENLA, por su esclarecedora insistencia en el valor de la "perseverancia";

Comisario Inspector P.P.B.A. Mario CRESPO, por su permanente atención para solucionar problemas;

Dr. Gustavo DE LA FUENTE, por su jovial amistad y por el aporte de sugestiva bibliografía;

Subcomisario P.P.B.A. Fernando DURANTE, amable amigo a través de los años;

Prof. Cecilia FERRANTINO, por su refinada capacidad para interpretar meticulosos requerimientos en materia de comunicación visual;

Ing. Juan FERRANTINO, por su buena voluntad; 
Dr. Sebastián IRAZUSTA BADI, por su brillante perspicacia para inquirir por mejores respuestas que aquellas que posee;

Comisario Inspector P.P.B.A. Prof. Lic. María del Carmen LOGÜERCIO, Directora del C.A.E.E.P. (Bahía Blanca) por sus valiosos aportes en materia del controversial "orden jerárquico";

Prof. Fernanda MERCERAT, por su exhaustiva dedicación para observar y sugerir el mejor estilo literario;

Prof. Dr. Atilio MILANTA por el apoyo y aliento brindados permanentemente a través de su ejemplo "sin prisa pero sin pausa", como él mismo suele decir, para que este trabajo salga a la luz;

Lic. Emilio MOLINA, por su elocuente expresividad en el silencio;

Comisario Mayor P.P.B.A. Gastón OCHOA, Director del C.A.E.E.P., por su gentileza e incuestionable vocación de servicio;

Dr. Emilio RAFFO, por su creciente y fraterno apoyo institucional desde la presidencia de LA PROTECTORA, Sociedad de Socorros Mutuos y actividades Sociales y Culturales, fundada en 1890 en la ciudad de La Plata, provincia de Buenos Aires;

Lic. María de las Mercedes RIAT, con quien comparto tantos encuentros a través del "Ewige Wiederkunft des Gleichen";

Ing. Sergio RUAU; por su inagotable, sorprendente y ejemplificadora creatividad para resolver dificultades;

Comisario Mayor P.P.B.A. Prof. Néstor VILLEGAS por la posesión de esa brillante habilidad para estar en el lugar adecuado y en el momento preciso.

Ricardo Torres Medrano Barranca de los Lobos, Mar del Plata, Marzo de 2012 



\section{Índice}

Who would these fardels bear,

To grunt and sweat under a weary life, But that the dread of something after deathThe undiscover'd country, from whose bourn No traveller returns-puzzles the will, And makes us rather bear those ills we have

Than fly to others that we know not of? ${ }^{4}$

In memoriam ................................................................. 5

Epítome Nietzscheano (de Atilio Milanta)..............................

Algunas motivaciones y gratitudes a la presente edición..................15

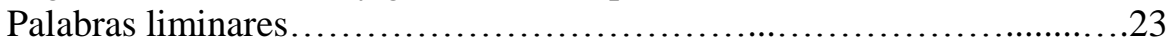

Scholium.....................................................27

PARTE I

El influjo de la sangre

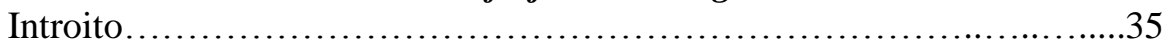

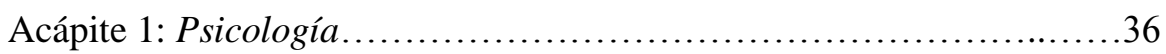

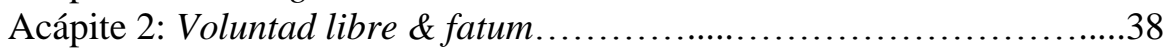

\section{PARTE II \\ Primer Período}

Introito.............................................................. 41

Acápite 1: Apolíneo \& dionisíaco.......................................42

Acápite 2: Los griegos antes \& después de Sócrates.......................45

Acápite 3: Cultura alemana del Siglo XIX..............................50

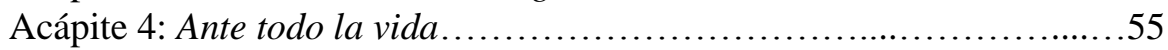

Acápite 5: Primera generación..........................................57 
Acápite 6: Genio.

\section{PARTE III \\ Segundo Período}

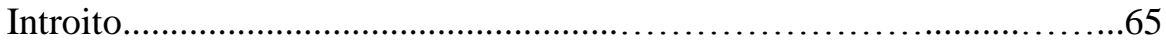

Acápite 1: Espíritu científico.....................................67

Acápite 2: Libre albedrío........................................70

Acápite 3: El bien \& el mal..............................................72

Acápite 4: Naturalezas fuertes \& naturalezas débiles...........................77

Acápite 5: Cultura superior \& cultura inferior................................79

Acápite 6: Vivir peligrosamente ....................................8 81

Acápite 7: Espíritu libre..........................................83

\section{PARTE IV \\ Tercer Período}

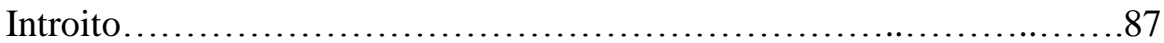

Acápite 1: Tentadores..............................................89

Acápite 2: Aristocrático \& plebeyo...................................... 91

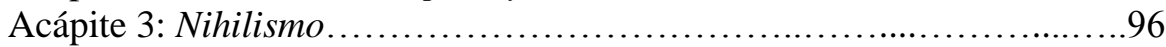

Acápite 4: Voluntad de poder......................................100

Acápite 5: Superhombre.........................................103

\section{EPÍLOGO}

Ocaso

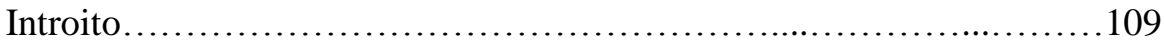

Acápite 1: Hombre crepuscular............................................110

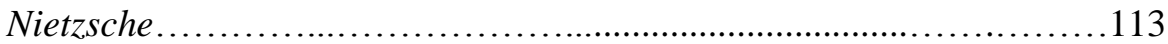

Narciso Pousa................................................................ 115

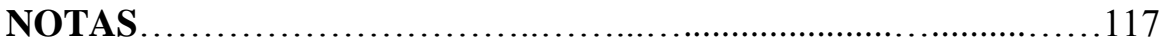


Überzeugungen sind gefährlichere Feinde der Wahrheit als Lügen ${ }^{5}$. 



\title{
Palabras liminares
}

\begin{abstract}
Virtue is of so little regard in these costermongers' times that true valour is turn'd berod; pregnancy is made a tapster, and his quick wit wasted in giving reckonings; all the other gifts appertinent to man, as the malice of this age shapes them, are not worth a gooseberry.
\end{abstract}

Según Nietzsche, a partir de la Revolución Francesa tenemos que estar preparados para "conmociones fundamentales"; desde entonces se producen acontecimientos que anuncian modificaciones infra y superestructurales ${ }^{7}$ para el próximo milenio ${ }^{8}$, con lo cual, el orden social se ajustará al rumbo de las "nuevas ideas". En la actualidad, los triunfos y logros de la civilización ponen en peligro el desarrollo mismo de la cultura ${ }^{10}$; son tiempos de procesos políticos extraordinarios o en otras palabras, de grandes luchas por el dominio de la tierra ${ }^{11}$.

Es así que se aproxima el "ocaso de los ídolos", es decir, la ruina de las verdades antiguas ${ }^{12}$ pues casi todo lo que hasta el presente se llama verdad es sólo mentira y, cuando la nueva realidad se enfrente a las fabulaciones milenarias, nuestra cosmovisión sufrirá terribles sacudidas; las guerras serán inevitables y todas las instituciones basadas en el engaño y la ilusión caerán ante el asombro de los sobrevivientes ${ }^{13}$.

Nietzsche inicia la desacralización o "desenmascaramiento" de las verdades eternas y la transmutación de todos los valores (Umwertung aller Werte) que son, en definitiva, procesos 
ineluctables. Asimismo, no hay fenómenos morales sino una "interpretación moral de los fenómenos" ${ }^{14}$, en todo caso, una falsa interpretación ("Mi $\beta$ "deutung) ${ }^{15}$. Y la moral no es otra cosa que una coacción prolongada (langer Zwang) ${ }^{16}$.

Para Nietzsche hay solamente un cristianismo: el que muere en la cruz; el Evangelio mismo muere también en la cruz y la "infección cristiana" " que se produce posteriormente es contraria a la práctica evangélica original, es decir, es un "mal mensaje" o un "Dysangelium"18. El cristianismo está arruinado por su propia moral; y lo que conocemos como "veracidad cristiana" exige saber qué significa la "voluntad de verdad"; según Nietzsche, su caída es inminente. Así comienza el espectáculo grandioso reservado para los siglos XX y XXI y esto es, "la muerte" de la moral ${ }^{19}$.

En la medida en que la Humanidad se aleja de la fe ${ }^{20}$, más se acerca a la Ciencia $^{21}$, porque mientras la primera significa no querer saber qué es la verdad, la segunda nos asemeja a Dios. Según Nietzsche, estamos en ese camino. Día tras día el Hombre se perfecciona mediante la investigación de la Naturaleza; forma un cuerpo físico, mental y espiritual cada vez más enaltecido, realiza experimentos para mejorar la nutrición, el modo de vivir, la manera de interpretar los fenómenos de la Naturaleza y la expansión de la conciencia; pero en última instancia, no se trata del Hombre, pues éste tiene que ser superado (überwunden werden) ${ }^{22}$.

Friedrich Wilhelm Nietzsche, el "primer inmoralista",23, muere muchas veces mientras vive; ése es el precio que tiene que pagar para ser inmortal ${ }^{24}$. Sabe que es necesario destruir para luego poder construir; o en otras palabras, morir para volver a nacer. Por eso es el "destructor "par excellence"" 25 ; y en ese caso, no duda en luchar contra su época ${ }^{26}$ y también contra las creencias de su mundo ${ }^{27}$. Rendimos aquí homenaje pues, al "último discípulo" de Dionisio $^{28}$, al "maestro del eterno retorno" 29 , al "hombre póstumo"30. 
Este trabajo representa la culminación de mi Licenciatura en Filosofía en la Facultad de Humanidades y Ciencias del Educación de la Universidad Nacional de La Plata. Por ello, quiero expresar mi agradecimiento a la Sra. Rosita Medrano Napal y al Sr. José Andrés Torres por su infatigable apoyo e ilimitada confianza y comprensión, aun en lo incomprensible; a la Prof. Lic. Claudia Llanos, quien iluminó mi camino durante estos últimos años; a la Sra. Carmen Medrano de Quevedo; al Prof. Ctdor. Elio R.F. Llanos; a la Prof. Ctdra. Cristina Gadea; a la Sra. Clyde Llanos y al Sr. Ricardo Ruarte, quienes me alentaron y contribuyeron, entre otras cosas, con importante bibliografía.

Deseo dar las gracias también al Prof. Dr. Rodolfo Gaeta, Director del Departamento de Filosofía de la Facultad de Humanidades y Ciencias de la Educación de la U.N.L.P., por la amabilidad y atención brindada para concretar los trámites de mi Licenciatura y a la Prof. Dra. Nora Rabotnikof, coordinadora de la Licenciatura en Sociología, por su buena voluntad.

$\mathrm{Y}$ por último, quiero manifestar mi más profundo reconocimiento al Prof. Narciso Pousa, el director e inspirador de este trabajo; en verdad un hombre en sentido pleno, un hombre libre, un auténtico filósofo, que no necesita distanciarse de nada ni de nadie porque en realidad vive muy alejado de las puerilidades académicas cotidianas y quien me ha mostrado, con su ejemplo, hasta qué extremo se cumple la máxima nietzscheana que dice: “...deine Erzieher vermögen nichts zu sein als deine Befreier" $"$.

“Alles geht, alles kommt zurück...,

“...meine Stunde kam"33.

Ricardo Torres Medrano

La Plata,

Octubre de 1990 



\section{Scholium}

The world is still deceiv'd with ornament.

In law, what plea so tainted and corrupt But, being season'd with a gracious voice,

Obscures the show of evil? In religion,

What damned error but some sober brow

Will bless it, and approve it with a text, Hiding the grossness with fair ornament? ${ }^{34}$

De acuerdo con Nietzsche, el momento más peligroso para la cultura alemana del siglo XIX, siglo científico-natural o saeculum obscurum $^{35}$, es el ocasionado por la influencia del hegelianismo, de los hegelianos y de sus "raquíticos retoños" que acostumbran a los alemanes a hablar de un "proceso universal" y justificar todas las épocas por el necesario resultado final de ese proceso. Esta interpretación de la Historia es considerada como la marcha de Dios sobre la tierra, en la cual Dios mismo no es otra cosa que una creación de la Historia. Por lo tanto, si cada acontecimiento es el producto de una necesidad racional, del triunfo de lo lógico o de la "Idea", no queda otra alternativa, pues, que someterse sumisamente a las propuestas de estos "abogados del diablo" y a todas las manifestaciones del éxito universal, por extrañas que puedan parecer.

Asimismo, el hecho de que casi toda la Humanidad vive, mientras los escasos grandes hombres mueren es indiscutiblemente una verdad, aunque una verdad atroz. En este sentido, la grandeza y virtuosidad de los individuos está dada por la capacidad de revelarse contra el poder de los hechos y las circunstancias. Es así que la Historia recuerda las grandes luchas "contra la Historia", contra el 
poder ciego de la realidad y exalta a las verdaderas naturalezas históricas, las que se ocupan de "lo que es" para acatar "lo que tiene que ser" y cuyo propósito último no consiste en destruir la sociedad, sino en crear una nueva ${ }^{36}$.

Por ello, llegará un tiempo en que se considerará más a las masas, pero en el cual la atención se volverá hacia los individuos que forman algo así como un puente sobre el eterno devenir. Incluso, las masas son imitaciones difusas de los grandes hombres, son la oposición que siempre tienen los grandes y son al mismo tiempo, instrumentos ya listos para ser utilizados por los grandes.

Sin embargo, según Nietzsche, eso no es un impedimento para que la Historia considere a los grandes movimientos sociales como lo más importante, o bien, conciba a los grandes hombres en cuanto manifestaciones acabadas de la masa, y a esta forma de organizar los acontecimientos como la más atractiva en la actualidad $^{37}$. Quien no quiere ser parte de la masa sólo tiene que evitarla, luego su conciencia le dirá: "iSé tú mismo! Tú no eres todo lo que ahora haces, piensas, deseas" "38. Cuando un hombre asume las limitaciones de sus cualidades y de su voluntad moral, le invade la tristeza y a la vez el deseo, con lo cual, la responsabilidad de su pecado lo lleva a imitar al santo, siempre que su intelecto le haga aspirar al genio. No obstante ello, cada uno tiene que elegir su propio y único camino y en el mundo no hay nadie mejor que uno mismo para alcanzarlo.

Será durante el primer período de su vida intelectual que Nietzsche reconoce los cimientos de una nueva e insólita cultura, formada por hombres invadidos por el deseo de renacer con un toque de genialidad o de santidad. Entonces el fin último de toda cultura es el genio, y su mayor aspiración es alcanzar la santidad.

En lo más hondo del ser de cada hombre se halla una originalidad productiva; y si uno es consciente de esto, una extraña aureola de lo extraordinario puede llegar a envolverlo. Además, si 
llega a ser un gran pensador sabrá que su labor consiste en ser un legislador de la medida de las cosas. El gran hombre es hijo de su tiempo, y aunque en apariencia lucha contra sí mismo, en realidad lucha contra su cultura o contra lo que puede impedirle llegar a ser grande, esto es, libre, entera y auténticamente él mismo ${ }^{39}$.

Por otro lado, según Nietzsche, los socialistas como tantos otros pretenden obtener el bienestar general; pero si ese "Estado perfecto" fuese alcanzado, la tranquilidad y conformidad cotidiana tenderían a suprimir las condiciones que permiten el desarrollo de las inteligencias superiores; en ese caso, la sociedad sería uniforme, es decir mediocre, por permitir el surgimiento de las individualidades especiales, de los genios, de los anormales positivos, en cualquiera de sus manifestaciones.

La vida es natural, violenta, transgresora; por lo tanto, todo aquello que es artificial y en principio invariable está condenado a desaparecer. En consecuencia, el hombre sabio tiene que oponerse a esas propuestas, porque de ello depende la persistencia de una clase extraordinaria, pues en un "Estado perfecto" sólo hay lugar para individuos cansados (ermattete Individuen $)^{40}$ y agobiados.

Todos poseen un "talento innato", pero sólo unos pocos elegidos consiguen de la Naturaleza, y por efecto de la educación, la cuota de energía, capacidad de trabajo y paciencia necesarias para desarrollar ese atributo y poder "llegar a ser" lo que ya "son" $"$. Por esto, la sociedad únicamente puede lograr una cultura superior (höhere Kultur) cuando llega a poseer dos castas diferenciadas entre sí: la de los dedicados al otium ${ }^{42}$, o trabajo libre en favor del conocimiento, y la de los trabajadores encargados de hacer todo tipo de trabajos en los que se requiere especialmente el uso de la fuerza física ${ }^{43}$.

Los socialistas, que proclaman la emancipación de los hombres oprimidos mediante la represión de los hombres libres, pretenden destruir todo el pasado como si realmente tuvieran el 
derecho para hacerlo, pero olvidan que la Historia de la Humanidad está escrita con sangre derramada durante siglos de violencia, esclavitud, engaño y error; según Nietzsche somos herederos de todos esos acontecimientos y no podemos modificarlos. En cuanto al problema de la propiedad, poseedores y desposeídos encierran sentimientos de injusticia, pero eso no los hace mejores, ni peores y tampoco les confiere un privilegio moral, pues seguramente ambos tienen algún antepasado con ius possidendi ${ }^{44}$. Por lo tanto, las transformaciones violentas no hacen otra cosa que cambiar el rol de los actores. Quizás, la solución para salir de este círculo vicioso se encuentra a partir de la introducción de cambios graduales que permitan afianzar en todos los individuos el sentimiento de legítima Justicia y a partir del establecimiento de claros contratos que recuerden a cada uno sus derechos y deberes ${ }^{45}$.

El socialismo, ese "hermano menor" del despotismo, que no sólo trabaja para abolir definitivamente las diferencias entre los que tienen y los que no tienen, sino que pretende lograr que nadie tenga para luego poder ocuparse de la anulación formal y material del individuo, vocifera su grito de batalla: "Más Estado como sea posible"46. Lo que sus seguidores aún no saben es que el tiempo equilibra los apesadumbrados gritos de unos y otros y la ninfa Eco se encargará de repetir ese clamor con una sutil diferencia: "Menos Estado como sea posible".

Además, el socialismo, como el nacionalismo, tienen dos pecados capitales a modo de fuerzas motrices: la pereza y la envidia. Unos quieren trabajar lo menos posible con las manos; los otros, casi nada con la cabeza. La sociedad propuesta por los primeros, fundada en relaciones materiales de producción, hace la vida individual inapelablemente triste, rutinaria y sin matices; la de los segundos, es una sociedad que odia y desprecia, al tiempo que mira con sumo interés, a las personalidades sobresalientes que no aceptan actuar en masa, aunque las reconozca y hasta las haya visto nacer ${ }^{47}$. 
En suma, la propuesta durante el segundo período de la vida intelectual del filósofo consiste en vivir como un espíritu libre, esto es, como hombres superiores (höhere Menschen) que no dejan de realizar los fines supremos de la civilización que consisten en bregar por el desarrollo íntegro y pleno del individuo. Es por esto que Nietzsche abriga un nuevo renacimiento ${ }^{48}$, a partir del cual el valor de todas las cosas será determinado otra vez ${ }^{49}$. De lo contario, habrá que asumir que donde hay dominación, hay masas; donde hay masas, hay necesidad de esclavitud; donde hay esclavitud, los individuos están en minoría y tienen contra sí mismos la voz de la conciencia colectiva y un aciago impulso que, no obstante motivarlos para la protección y los cuidados mutuos, los acobarda crecientemente pues actúa el instinto del rebaño (Herdeninstinkte) ${ }^{50}$.

"Ecrasez l'infâme" y superflua burla" "52, la "rebelión de esclavos" 53 que se inicia con el pueblo judío ${ }^{54}$, como todos los movimientos democráticos, constituye el legado del cristianismo cuya intención es contraria a las castas, a los aristócratas y, aunque sólo en sentido formal, a los privilegios $^{55}$. Este movimiento social crea las condiciones para que los anarquistas aparentemente enfrentados a los demócratas (ideólogos de la Revolución) y a los socialistas que quieren la "sociedad libre" coincidan en las conductas siguientes: el desprecio hacia toda sociedad distinta de la del rebaño "autónomo" y la resistencia contra los privilegios o contra todo derecho, pues cuando todos son iguales no se necesitan derechos (a partir de la creencia en la moral de la compasión "comunitaria" y, entre otras cosas, con la convicción de que la comunidad es la única redentora social ${ }^{56}$ ).

Nietzsche considera el movimiento democrático no como forma de decadencia de la organización política, sino como degradación de los valores, como mediocrización social y, por consiguiente, empequeñecimiento del género humano. Por lo tanto, es preciso acudir a "nuevos filósofos", a espíritus fuertes y 
originales, a recios hombres de mando ${ }^{57}$, para reemplazar los consabidos "valores eternos", para transvalorar, para crear nuevos valores, para enseñar a los hombres que su futuro siempre depende de una voluntad humana. Y como los contrarios se concilian en la síntesis, en este caso sucede en la democracia pues las nuevas condiciones bajo las cuales se pueden producir la nivelación e igualdad en la Humanidad, en el sentido de originar animales de rebaño útiles y laboriosos, son propicias también para dar nacimiento a portentosos hombres de sorprendentes y atractivas características. En consecuencia, mientras la democratización de Europa está encaminada a formar hombres aptos para la esclavitud, los hombres fuertes resultan ser incomparables e infatigablemente duros, debido a su educación libre de prejuicios. Y aunque denominemos a este movimiento "civilización", "humanización" o "progreso", es un medio para procrear impensados e inigualables conductores excepcionales, no sólo en sentido material sino también y, de manera específica, en sentido espiritual ${ }^{58}$.

Nietzsche se encuentra consagrado en el tercer período de su vida intelectual a aquello que denomina el "problema europeo", es decir, la formación de una nueva casta encargada de gobernar Europa $^{59}$. Lo extraordinario está destinado sólo para las personalidades notables y valiosas ${ }^{60}$; por eso, "el hombre más grande" suele ser el más solitario, el más recóndito, el más desconforme; el que se sitúa más allá del bien y del mal, dueño de sus virtudes y de sus pasiones, por poseer una firme voluntad y porque la grandeza consiste en ser tan múltiple como completo, y tan exclusivo como pleno ${ }^{61}$. Sin embargo, penetrar en un mundo elevado presupone del mismo modo haber nacido para él; por lo tanto, el derecho a vivir en la Filosofía solamente se obtiene por una ascendencia adecuada, es decir, por el ius sanguinis ${ }^{62}$. Varias generaciones en un mismo tronco familiar tienen que incidir cuidadosamente para que surja el auténtico filósofo; sus virtudes 
tienen que ser heredadas, adquiridas y cultivadas para que se manifieste el desarrollo intrépido y minucioso de sus pensamientos, la presteza para las enormes responsabilidades, la soberbia de las miradas dominadoras y descendentes, el irrefrenable empeño para apartarse de la multitud, y de su decrépita moral, y la inquebrantable actitud de defender permanentemente todo aquello que suele ser malentendido ${ }^{63}$.

El filósofo alienta a estas naturalezas a permanecer perseverantes y duras (hart) en favor de su propia voluntad de poder y con el propósito de lograr la superación de la Humanidad ${ }^{64}$. Además, éstas tienen que vivir al margen de la moral tradicional, con lo cual se encuentran obligadas a fundar sus propias leyes, normas, Artes y astucias de "autoconservación", "autoelevación" y "autorredención". Ahora bien, tanto los medios como los fines son enteramente nuevos excepto para quienes permanecen incurablemente invariables, es decir, los mediocres ${ }^{65}$, los más rutinarios e iguales entre sí que tienen la ventaja de ser numerosos. En cambio los más independientes ${ }^{66}$, los que son sin tener la obligación de serlo, los más selectos, los insólitos y difíciles de comprender, viven frecuentemente aislados, perecen ante el menor accidente y casi nunca procrean ${ }^{67}$; son pues, dueños de las cuatro virtudes: "valor", "inteligencia", "simpatía" y "retraimiento"68 (el tan importante y obligado retraimiento, indispensable para evitar la vulgaridad que infunde el ritmo de cualquier sociedad).

Sólo cuando la Humanidad se sacrifica en función de la prosperidad de una especie de hombres "más fuertes" ${ }^{69}$, más inmorales, más naturales, se alcanza un progreso (fortschritt) ${ }^{70}$. Por el contrario, pretender equiparar la propia voluntad a la de los demás individuos, a modo de "principio fundamental de la sociedad", es promover una voluntad de negación de la vida; porque la vida en la Naturaleza es apropiación, violencia, opresión, dureza e imposición. El latrocinio es parte de lo vivo y, desde un punto de vista orgánico, 
es también una consecuencia de la voluntad de poder, es decir, de la voluntad de vivir ${ }^{71}$.

En consecuencia con lo dicho, el propósito del presente trabajo consiste en brindar una interpretación de la propuesta nietzscheana de "Autosuperación del Hombre" en relación con los diferentes períodos de la vida intelectual de Nietzsche; la misma se inscribe en el marco de una teoría política contraria a las doctrinas antes mencionadas: la filosofía de la historia hegeliana, el socialismo, el nacionalismo, el anarquismo, la democracia y el cristianismo.

Y para finalizar, cabe aclarar que al momento de traducir un texto a otro idioma, hay que tener presente dos alternativas: $\mathrm{O}$ bien realizar una traducción literal, o bien realizar una traducción literaria. En cualquiera de los dos casos, corremos el riesgo de traicionar el espíritu que animó al autor del texto; pues como todos sabemos, una traducción literal difícilmente representa lo mismo en otro idioma. Mientras que una traducción literaria, en definitiva tampoco significa con precisión aquello que el autor del texto original quiso decir. Por lo tanto, nos encontramos a las puertas de un dilema, pues en el primer caso traicionamos el espíritu de una lengua; y en el otro, traicionamos al autor. En consecuencia y lejos de pretender ser un traidor en cualquiera de sus acepciones, trato de representar con la mayor fidelidad posible aquello que quisieron decir los autores en cuestión, Nietzsche fundamentalmente y Shakespeare, en los epígrafes de cada capítulo; como también me he propuesto hacer inteligible al lector de habla hispana lo que originalmente fue escrito en Alemán y en el Inglés moderno temprano. 


\section{PARTE I \\ El influjo de la sangre}

\section{Introito}

To die is to be a counterfeit;

for he is but the counterfeit of a man who hath not the life of a man; but to counterfeit dying, when a man thereby liveth, is to be no counterfeit, but the true and perfect image of life indeed.

Los primeros años de la vida intelectual de Nietzsche (niñez y juventud) no constituyen un período claro y homogéneo en el desarrollo intelectual del filósofo, como los tres períodos conocidos tradicionalmente que veremos más adelante; sin embargo, podemos considerar esta etapa como la lenta gestación de las condiciones que darán origen a las concepciones de los períodos posteriores. No podemos decir que por estos años haya una explícita formulación de la "Autosuperación del Hombre" pero sí hay alusiones que permiten entrever aquello que ya está en potencia. Esta etapa está impregnada de un pathos ${ }^{73}$ pastoral, de rigurosa filología clásica propia de Pforta (o Schulpforta, la escuela inicial) y de música vocacional; son los años en que comienzan las migrañas y en los cuales también recibe tratamiento médico a causa de una posible infección sifilítica, son los años de "primum vivere, deinde philosophari"" . 


\section{Acápite 1: Psicología}

Desde sus primeras manifestaciones intelectuales, podemos advertir en Nietzsche un notable sentido de pertenencia a la sólida tradición familiar, basado en una profunda creencia en la predeterminación de los rasgos característicos de la personalidad a partir de los antepasados o, en otras palabras, un intenso sentimiento de pertenencia a un linaje que además se mantendrá a lo largo de toda su vida. En estos años, las lecturas acerca de las investigaciones de Darwin marcan un rumbo en la dirección de su pensamiento. En todo caso, sólo demuestra tener un interés mínimo por indagar la historia de su árbol genealógico.

Ahora bien, la etimología del nombre patronímico Nietzsche indica los prenombres Nikolaus, Nick, influenciado por el eslavo Nitz, y al altoalemán antiguo "nît", que denota fundamentalmente celo, odio. Tal vez algunos autores, como Janz, pretendan sugerir que la relación entre el nombre y lo nombrado no es arbitraria sino natural y necesaria ${ }^{75}$. Y si esto es así, debiera haber algo más que una 
relación casual entre signo y significado. De cualquier modo, no lo vamos a desentrañar ahora.

En cuanto a los antecedentes profesionales de los antepasados de Nietzsche, en general, sobre todo por la línea paterna que por línea materna, parten de la burguesía acomodada y concluyen en la profesión de pastor protestante. Nietzsche proviene de familias tradicionales de pastores que, asimismo y principalmente en Suabia y Sajonia-Turingia, dan origen a muchísimos talentos en la poesía, en el pensamiento y en ambos ${ }^{76}$.

Por otro lado, Max Oehler ${ }^{77}$ demuestra al comparar la nómina de antepasados de Nietzsche con los árboles genealógicos de otras personalidades talentosas, que hay cierto grado de parentesco entre nuestro autor y las siguientes celebridades: Richard Wagner, Johann Elias Schlegel, August Wilhelm y Friedrich Schlegel, August Neithart von Gneisenau, Samuel von Pufendorf y Julius Sturm, entre otros. Nietzsche es consciente de esta tradición sólo en parte, aunque tal vez lo suficiente para que sus primeros años, los decisivos, sean determinados por ella; y aun cuando no hubiese sabido nada de sus antecedentes familiares, el linaje, la sangre -como él pensaba- se habría encargado del resto. 


\section{Acápite 2: \\ Voluntad libre \& fatum}

Nietzsche entiende que no sólo estamos determinados por las influencias de nuestros padres, sino que también estamos regidos por las impresiones infantiles, las costumbres y por todo lo que se relaciona con nuestra educación en general; lo estamos tan hondamente que los prejuicios no pueden ser eludidos con sólo desearlo.

De la misma manera que la costumbre es el resultado de una época en la que vive un pueblo y de cierta dirección del espíritu, la moral es el resultado del desarrollo de la Humanidad, la que consiste en la totalidad de las verdades para nuestro mundo. En este sentido, posiblemente la "verdad universal" llegue a ser el resultado de la suma de verdades de los diversos mundos. Tal vez la Humanidad no sea otra cosa que un escalón (Stufe), un período en lo general (Periode im Allgemeinen) en el constante devenir o un eslabón más en la amplia escala evolutiva. En consecuencia, para Nietzsche el Hombre es un fin $(Z w e c k)^{78}$, pero también es transformación (Veränderung) y lo advertimos en las diferentes épocas: 
F.W. NIETZSCHE: Autosuperación del Hombre

"Cómo podríamos asimismo nosotros ver planes superiores. Nosotros vemos solamente, cómo de las mismas fuentes, en la Humanidad se forman ideas bajo las impresiones externas; cómo estas adquieren vida y forma; vienen a ser todo bien público, conciencia, sentimiento de deber; cómo el eterno impulso de producción las trabaja a nuevo como materia, cómo ellas forman la vida, rigen la Historia; cómo ellas toman parte en luchas de unos contra otros y cómo de esta mezcla surgen nuevas formaciones. Un luchar y ondular de las corrientes más diferentes con flujo y reflujo, todas hacia los eternos océanos" ${ }^{79}$.

Luego, advierte Nietzsche, las almas de la gente son arrastradas hacia lo vulgar, con lo cual se dificulta un mayor vuelo espiritual. Probablemente las causas sean una "estructura fatalista" del cráneo y de la columna vertebral y el estado y naturaleza de sus padres. Somos influenciados sin saberlo y sin tener la fuerza suficiente para resistirlo.

"El fatum predica siempre nuevamente el principio fundamental: Los acontecimientos son lo que los acontecimientos determinan. Sería éste el único verdadero principio fundamental, así es el Hombre un juguete de obscura fuerza eficiente, inexcusablemente para su vicio, en general libre de diferencias morales, un eslabón necesario en una cadena. ¡Feliz, cuando él su situación no trasluce, cuando él no palpita convulsivamente en las ataduras que le envuelven, cuando él no intenta con demente regocijo el mundo y su mecanismo confundir! ",80.

\section{Y más adelante concluye:}

"La Historia Universal es entonces Historia de la materia, si uno capta ampliamente el significado de estas palabras. Pues tiene que conceder aun principios superiores, ante los cuales todas las diferencias se funden en una gran unidad, ante los cuales todo desarrollo es evolución, todo fluye a inmensos océanos, en donde se halla de nuevo toda palanca evolutiva del mundo, unido, mezclado, todo en uno",81. 
Los acontecimientos marcan nuestro destino y la dureza o debilidad con que se presentan depende de nuestro temperamento para enfrentarlos. La voluntad libre (freie Wille) es lo infinitamente libre, mientras que el fatum es una necesidad porque se refiere a nuestro propio "destino"; el fatum y la voluntad libre se encuentran enfrentados aunque son inseparables.

El fatum es una fuerza sin materia, una cadena de acontecimientos; cada hombre modela su propio fatum cuando actúa y produce sus acontecimientos, con lo cual esta actividad no solamente empieza en el momento de nacer, sino también en el embrión, en sus padres y antepasados. Es el principio que nos rige al actuar inconscientemente como un simple dejarse llevar por impresiones anteriores (Sichleitenlassen von frühern Eindrücken), sitúa al individuo en relación con la evolución general y lo estimula a activar fuerzas reactivas tan pronto como aquella pretende dirigirlo y dominarlo. Para un hombre sólo hay un fatum individual. La voluntad libre en cambio, representa la capacidad de actuar conscientemente, en tanto que en el libre albedrío (Willensfreiheit) se reduce el principio de la singularización (Princip der Absonderung), de la diferenciación respecto del todo, del absoluto carácter ilimitado ${ }^{82}$.

En la medida en que las cosas se alejan de lo inorgánico y se acomplejiza la materia y la forma, más sobresaliente se hace la individualidad y más variadas son sus propiedades. El principio fatalista solo, convertiría a un hombre en un autómata; mientras que una voluntad absolutamente libre, sin fatum, lo transformaría nada menos que en un dios ${ }^{83}$. 


\section{PARTE II}

\section{Primer período}

\section{Introito}

All that glisters is not gold, Often have you heard that told;

Many a man his life hath sold

But my outside to behold. Gilded tombs do worms infold. ${ }^{84}$

Este período comienza el 28 de Mayo de 1869 cuando Nietzsche, ya admitido por la Universidad de Basilea para desempeñarse como catedrático extraordinario de Filología Clásica, da su lección inaugural: "Homero y la filología Clásica" ("Homer und die Klassische Philologie"); y se extiende hasta el 10 de Julio de 1876, fecha de la publicación de "Richard Wagner en Bayreuth" (Richard Wagner in Bayreuth), cuarta parte de las Consideraciones Inactuales (Unzeitgemässe Betrachtungen).

En estos años se identifica con la filosofía inactual de Schopenhauer y la música vitalista de Wagner; ataca a Sócrates y a la cultura científica que exalta al especialista en detrimento del genio, del creador. En estos años cree intensamente que "philosophia facta est quae philologia fuit" ${ }^{\mathrm{85}}$. 


\section{Acápite 1: \\ Apolíneo \& dionisíaco}

En el curso de las investigaciones que Nietzsche lleva a cabo acerca del nacimiento y muerte de la tragedia griega, surge claramente que sólo podemos representarnos y comprender a los griegos si logramos responder "qué es lo dionisíaco" concepción estrictamente artística y hasta puede ser "anticristiana" ${ }^{87}$. Como la vida animal, que es el resultado del encuentro vehemente de los sexos, el desarrollo progresivo del Arte es obra de lo apolíneo y lo dionisíaco. Los antecedentes debemos buscarlos en la mitología griega, precisamente en las características de las dos divinidades, Apolo y Dionisio. Ellos son quienes provocan la contraposición que se da entre la escultura y la música, entre el Arte apolíneo y el Arte sin formas o Arte dionisíaco. Son dos instintos opuestos pero inseparables entre sí porque se complementan mutuamente. En el caso de la tragedia griega, se necesita de uno y otro para dar nacimiento a la obra de Arte, un tanto apolínea, un tanto dionisíaca ${ }^{88}$; son incluso, como los dos mundos estéticos del "sueño" y la "embriaguez" 89 . 
Apolo, dios adivinador, dios de las facultades creadoras de las formas, representa la apariencia radiante como el sol, como la luz. Podemos encontrar en Apolo la magnífica imagen del principio de individuación que nos muestra al mismo tiempo la belleza y la sabiduría de la apariencia. La vida no sólo es posible, también merece ser vivida por esa aptitud de la adivinación y por las Artes, analogía simbólica pues del sueño y la embriaguez, como prosigue Nietzsche ${ }^{90}$. La naturaleza dionisíaca, semejante a la embriaguez, actúa como si hubiese sido excitada por un narcótico o, asimismo, por el irrefrenable poder de la primavera que invade toda la Naturaleza ${ }^{91}$. Bajo el efecto de los encantos dionisíacos se manifiesta la alianza de los hombres entre sí; y la Naturaleza, en parte sometida, en parte aun misteriosa, se reconcilia finalmente con su dominador ${ }^{92}$. Es el momento en que señores y esclavos se liberan de todos los obstáculos que la tradición, la arbitrariedad o la moda-moral los separa. Es, en otras palabras, la representación pictórica del "Himno de la Alegría" de Beethoven; todos y cada uno son simplemente uno con la Unidad primordial.

Y así, al son de la música y de la danza, con una encantadora beatitud, los hombres pasan a ser miembros de una comunidad superior (höheren Gemeinsamkeit) ${ }^{93}$. A partir de ese momento sus integrantes se sienten dioses, tal vez como en los sueños de sus sueños; y de esta manera, a causa de la embriaguez, dejan de ser artistas para convertirse finalmente en obras de Arte ${ }^{94}$. Estos dos instintos contrarios, lo apolíneo y lo dionisíaco, puestos de manifiesto como fuerzas artísticas, surgen desde lo más profundo de la Naturaleza; y luego, casi sin la intervención del artista, pueden satisfacerse mutuamente al instante ${ }^{95}$.

El éxtasis dionisíaco provoca un estado en el que desaparecen todos los recuerdos personales, como si un abismo separara los dos mundos, el de la realidad dionisíaca y el de la realidad diaria. Luego, cuando se acortan las distancias y el individuo se encuentra 
nuevamente con la realidad cotidiana, no puede sentirse con ella de otra manera que disgustado y opta, en consecuencia, por convertirse en un asceta.

Por esto observa Nietzsche, el hombre dionisíaco es semejante a Hamlet pues ambos "conocen"; llegan hasta el fondo de las cosas y saben que, cualquiera que fuese la acción, su esencia no cambiará; no tendría sentido pues, intentar reconstruir un mundo que cae día tras día. El conocimiento detiene la acción, por eso es preciso fascinarla mediante la ilusión; el conocimiento es entonces lo que nos revela la horrible verdad, suprimiendo cualquier motivo para actuar. A Hamlet y al hombre dionisíaco les sucede lo mismo: no les queda lugar para el consuelo, tienen otra noción de la existencia y la desdeñan como desprecian a sus dioses.

Ahora la verdad nos permite percibir todo el absurdo de la existencia. Es aquí donde reaparece el Arte, pues sólo él puede cambiar nuestra disposición ante la existencia mediante imágenes que nos hagan la vida más tolerable. Esas imágenes son lo "excelso" y lo "cómico"; mediante la primera, lo artístico aprende a dominar a lo espantoso, y mediante la segunda, lo absurdo ya no nos resulta tan desagradable ${ }^{96}$. 


\section{Acápite 2:}

\section{Los griegos antes \& después de Sócrates}

Ahora bien, durante la existencia de la tragedia griega, el único héroe es Dionisio. En tiempos de Eurípides, e incluso antes, Dionisio nunca deja de ser el auténtico héroe trágico. En otras palabras, Prometeo, Edipo y todos los célebres personajes del antiguo teatro griego son sólo disfraces de Dionisio; luego, concierne a Apolo otorgarles certeza y claridad para que se manifiesten pues él es quien interpreta los sueños. No obstante la causa de la "idealidad", tantas veces admirada en y por esos personajes, es porque detrás de las máscaras se halla oculto un dios ${ }^{97}$.

Asimismo, y no obstante reconocer que el uso y vigencia de los mitos son asuntos muy discutibles, Nietzsche observa que Dionisio deja la escena trágica a causa de un poder demoníaco; en este caso, Eurípides aparece sólo con una máscara, pues quien habla ya no es Dionisio, ni siquiera Apolo. Más que una divinidad es un nuevo demonio, su nombre: Sócrates. Ahora la contraposición se produce entre lo dionisíaco y lo socrático; y es esta última en 
definitiva, la razón por la cual perece la obra de Arte de la tragedia griega $^{98}$.

Eurípides es el actor que proyecta el plan de su obra a la manera de un pensador socrático y lo monta en escena como un artista apasionado. Sin embargo, no hay Arte en el proyecto ni en la actuación; su drama sirve para expresar a la vez tanto apatía como fervor. Dicho en pocas palabras, ha perdido todo lo que tenía de apolíneo y de dionisíaco. No obstante, tiene que conmover a, e influir en, su auditorio; para lo cual necesita nuevos medios de emoción, los que ya no están sujetos a aquellos impulsos artísticos originarios.

En lugar de contemplaciones apolíneas y éxtasis dionisíacos, ahora los medios a usar son "ideas paradójicas" y "afectos ardientes". Este "socratismo estético" está basado en la renombrada máxima que dice: "Sólo el que posee conocimiento es virtuoso". Desde ahora en adelante, y de acuerdo con este principio, Eurípides corrige todos los elementos de la tragedia, es decir, la lengua, los personajes, la construcción dramática y la música del coro ${ }^{99}$. Hasta el mismo Sócrates pronuncia la máxima más impactante sobre el nuevo valor del conocimiento al confesar que no sabe nada. En cambio, los hombres de Estado, los oradores, los poetas y los artistas sobresalientes, si bien tienen pretensiones de sabiduría, no llegan a tener conocimientos precisos ni verdaderos; obran pues sólo por instinto (Nur aus Instinkt). Es con esas palabras que el socratismo cuestiona y condena el Arte y la Ética de su época. Y así sin más, cree un deber modificar la concepción de la existencia, convirtiéndose en el precursor de un Arte, de una nueva Moral y de una cultura, cuyo legado conservamos y defendemos orgullosamente hasta nuestros días ${ }^{100}$.

En lo tocante al proceso de productividad, en todos los hombres el instinto es la fuerza creadora, mientras que la conciencia sólo cumple una función crítica; pero en Sócrates sucede lo contrario, es decir, el instinto se muestra crítico y la conciencia, creadora ${ }^{101}$. 
Además, la doctrina socrática posee la ingenuidad y la seguridad tan característicamente propias de las divinidades. Sócrates presiente todo esto; y prueba de ello es la manera con que se vale de su predestinación, más precisamente ante sus jueces. Incluso es posible que el mismo Sócrates haya planeado en su totalidad los detalles de la trama, para convertirse, luego de solicitar la pena de muerte, en el nuevo ideal de los nobles jóvenes griegos ${ }^{102}$.

Sócrates, "lógico despótico", "héroe dialéctico del drama platónico", justifica sus actos mediante argumentos y razones; su optimismo dialéctico se impone inexorablemente en todas las conclusiones. Asimismo, los principios del optimismo que ocasionan la muerte de la tragedia son "virtud es conocimiento", "sólo se es malo por ignorancia" y "virtuoso es el que es feliz"; por ello y desde ese momento, el héroe virtuoso tiene que ser dialéctico ${ }^{103}$. Si el artista, ante toda manifestación de la verdad se aparta de lo que es claro y revelador, observa fascinado aquello que, no obstante esa claridad, continúa todavía inexplicable, el hombre teórico se deleita con el espectáculo del misterio revelado y halla el goce supremo en el descubrimiento de una nueva verdad que se impone triunfadora por sí misma.

Sócrates es el primer hombre que vive y hasta es capaz de morir en nombre de la actitud científica; y por esto, liberado a partir de la visión racional de su horroroso e irrevocable destino, se convierte en el emblema más adecuado para la Ciencia, pues recuerda a quienes dedican su vida a ella y cuyo firme propósito es hacer la existencia entendible para poder justificarla. Es el caso de Gotthold Ephraim Lessing, que gozaba más con la búsqueda de la verdad que con la verdad alcanzada ${ }^{104}$. En consecuencia, las tareas más nobles para el hombre socrático, y las más dignas para la Humanidad, consisten en investigar las causas en la Naturaleza y poder diferenciar el conocimiento verdadero del aparente, que es sólo error. 
Aquel que ha experimentado la satisfacción de poseer el conocimiento socrático, que en definitiva pretende dominar el mundo fenoménico, no tiene motivación más profunda para vivir que el irresistible anhelo de continuar la empresa hasta el final. De esta manera, Sócrates surge como el maestro de una nueva forma de "jovialidad griega", de una original y alegre manera de vivir que actúa con eficacia e influye formativamente en los jóvenes con el objeto de fomentar en ellos "el genio"

Ahora bien, si la tragedia griega comienza a morir cuando la tendencia dialéctica, orientada hacia el saber y el optimismo de la Ciencia, con sus propios actos morales logra rápidamente ganar adeptos entre los jóvenes griegos, Nietzsche concluye que hay una eterna lucha entre dos concepciones del mundo: la visión trágica del mundo (tragischen Weltbetrachtung) y la visión teórica del mundo (theoretischen Weltbetrachtung). De esta manera, cuando el espíritu de la Ciencia, es decir, la esperanza de llegar a racionalizar la Naturaleza mediante leyes para conseguir la panacea universal, haya alcanzado los límites infranqueables del saber y reconozca ineludiblemente que sus pretensiones de validez universal son un sinsentido, podremos augurar un renacimiento de la tragedia de $\operatorname{antaño~}^{106}$.

En otras palabras, la Ciencia impulsada por una ilusión crece con el afán de alcanzar sus propios límites pero sin haber llegado jamás a aprehender la totalidad de dichos límites. Asimismo, cuando algunos de los infinitos puntos extremos que los componen son alcanzados por los hombres más inteligentes y ante los cuales, es decir ante lo inexplicable, permanecen maravillados ${ }^{107}$, en ese preciso momento el babélico optimismo de los lógicos se detiene.

Según Nietzsche, encontramos en los antiguos griegos dos modos de vida diferentes ${ }^{108}$ : por un lado, una hermosa "ingenuidad" (herrlichen "Naivität") que debe ser considerada como "la flor de la cultura apolínea" con su original bella reflexión sobre la pasión 
(Schönheitsspiegelung über das Leiden) y su sabiduría del sufrimiento (Weisheit des Leidens); y por otro lado, una serenidad del "hombre teórico" (Heiterkeit des "theoretischen Menschen") enfrentado al Arte y a la sabiduría dionisíaca pues pretende reemplazar el mito por la revelación de los secretos de las fuerzas de la Naturaleza, precisamente porque cree que el saber mejorará el mundo y la Ciencia hará lo mismo con la vida. 


\section{Acápite 3: \\ Cultura alemana del Siglo XIX}

Para Nietzsche, lo que llamamos cultura actúa como un narcótico para mitigar el hastío que produce la existencia; luego los hombres se apegan a ella fascinados por una ilusión. Algunos lo hacen por el "placer socrático del conocimiento", otros por la "seducción del velo de belleza del Arte" y otros, finalmente, por el "consuelo metafísico de que la vida eterna fluye hacia adelante invariable". Además, los distintos narcóticos se encuentran mezclados entre sí, y según las proporciones de cada uno, será el resultado de la cultura. Esto es, más o menos "socrática", "artística", "trágica" o, para utilizar ejemplos históricos, "alejandrina", "helénica" o "india" (brahmánica), respectivamente.

Ahora bien, la cultura del mundo moderno es, sin duda, socrática o alejandrina, pues su modelo de vida es encarnado por el hombre teórico cuyos conocimientos son puestos al servicio de la Ciencia $^{109}$ (aclaremos que la cultura alejandrina, siguiendo a Nietzsche, se basa en supuestos esclavistas). Pero por otro lado, la cultura socrática oculta la ilusión del optimismo que, en lo tocante a 
la existencia, se opone a la esclavitud. Esto significa que la cultura contemporánea encierra en sí misma una clara contradicción y frases tales como "dignidad del Hombre" y "dignidad del trabajo" no pueden evitar su cada vez más notoria ruina. Y mientras la catástrofe de la cultura teórica preocupa cada vez más al Hombre moderno que busca -no sin dudar de los resultados- alguna solución, comienza igualmente a percibir los efectos de sus propios errores; tanto ahora como antes, algunas personalidades descollantes saben usar la Ciencia con perspicacia para probar, a partir de sus límites, la relatividad del conocimiento y luego reconsiderar el pretendido valor y eficacia de la Ciencia misma.

Nietzsche enuncia proféticamente que la sabiduría reemplazará a la Ciencia en calidad de fin supremo. La cultura socrática ya no defiende sus pretensiones de infalibilidad como lo hizo desde un principio; no sólo teme a sus inminentes consecuencias sino que tampoco confía en sus propios fundamentos. El fin se aproxima y la "quiebra" de la civilización es un indicio pues se contrae el espíritu optimista, en otras palabras, el germen del exterminio (Vernichtungskeim) y se declara la enfermedad primitiva de la cultura moderna (Urleiden der modernen Kultur). Con esto, el Hombre teórico se encuentra atemorizado y decepcionado por las consecuencias de su propio sistema; todo se le escapa de las manos y ahora la vida le parece cruel. Además, sabe que una cultura basada sobre los presupuestos de la Ciencia se derrumba cuando no tiene otra alternativa que retroceder ante sus propias consecuencias, es decir, cuando la lógica de la Ciencia se torna ilógica. En cambio, prosigue Nietzsche, si podemos concebir una nueva generación de hombres de mirada intrépida (Unerschrockenheit des Blicks), capaces de enfrentar lo monstruoso con aire heroico (heroischen Zug); incluso, si imaginamos un matador de dragones (Drachentöter) o simplemente, seres que dan la espalda con orgullo a las 
inconsistentes enseñanzas optimistas, no estamos pensando sino en una estirpe resuelta a vivir (resolut zu leben) plenamente ${ }^{110}$.

Nietzsche sostiene que desde el "fondo dionisíaco del espíritu alemán" surge una fuerza que no se parece en nada a los principios de la cultura socrática, una energía que dicha cultura no puede interpretar; sólo tiene en claro que es terrible e inexplicable (Schrecklich-Unerklärliche), prepotente y hostil (ÜbermächtigFeindselige). Es pues la música alemana, especialmente desde las obras de Bach hasta las de Beethoven y luego desde las de Beethoven hasta las de Wagner; ellas representan el espíritu del fuego purificador (lautere und lauternde Feuergeist). Además Nietzsche reconoce que mediante la influencia de Kant y Schopenhauer la Filosofía alemana logra desenmascarar al orgulloso modo de vivir del socratismo científico mientras pone de manifiesto sus propias limitaciones. Posteriormente, esta demostración da origen a una concepción que tiene la profundidad requerida para tratar las cuestiones éticas y del Arte; es pues la sabiduría dionisíaca (dionysische Weisheit). Por lo tanto, esta relación entre la Música y la Filosofía alemanas es la manifestación de una forma de existencia que sólo podemos interpretar a partir del análisis de las semejanzas con el mundo helénico. Según Nietzsche tenemos que entender estos acontecimientos como un retroceso desde la época alejandrina hasta el período de la tragedia pero, en definitiva, no significan otra cosa para el espíritu alemán que un regreso a su propia naturaleza después de un lapso de sometimiento debido a influencias de fuerzas externas ${ }^{111}$. La era del hombre socrático ya queda atrás y con el renacimiento de la tragedia volvemos a creer en la vida dionisíaca (dionysische Leben $)^{112}$.

Por consiguiente y para comprender la facultad dionisíaca (dionysische Befähigung) de un pueblo, hay que considerar a dos testigos fieles: sus mitos trágicos y su música. En efecto; de la misma manera que valoramos a un hombre por la capacidad para orientar 
sus actos hacia lo eterno y por percibir el significado metafísico de la vida, valoramos a los pueblos. En cambio, si un pueblo sólo se concibe históricamente y derriba sus mitos, entonces corroe las bases de sus propios fundamentos, su futuro, su grandeza, porque en los relatos antiguos se encuentra depositado el "inconsciente metafísico de su existencia anterior" 113 . En cuanto a la música, contribuye a intuir la universalidad dionisíaca y luego deja surgir una figura análoga en su más "elevada significatividad". Asimismo, tiene la facultad de dar nacimiento al mito y más precisamente al mito trágico que expresa en parábolas el conocimiento dionisíaco ${ }^{114}$. Es también un elevado medio de representación para dar movimiento al mundo plástico del mito; y en el caso del mito trágico, le confiere la significatividad metafísica que la palabra y la imagen por sí solas no $\operatorname{logran}^{115}$. En este sentido, tenemos que entender el mito trágico ${ }^{116}$ como una simbolización de la sabiduría dionisíaca a través de medios artísticos apolíneos; mientras que el mito ${ }^{117}$, sólo como una visión del mundo trasladada en conjunto. El mito trágico, en cuanto parte constitutiva del Arte, transfigura la realidad de un mundo de apariencias para exhibir descarnadamente ese mundo de apariencias, y esto no es otra cosa que el designio metafísico del Arte ${ }^{118}$. La música y el mito trágico, inseparables entre sí aparentemente, son en definitiva la manifestación de la facultad dionisíaca de un pueblo ${ }^{119}$.

Ahora bien, dada la relación entre la música y el mito, es dable esperar que la desaparición de éste ocasione la decadencia de aquélla. Por lo tanto observa Nietzsche, en la cultura alemana contemporánea la tendencia antiartística del optimismo socrático se revela en la ópera (antes de la llegada de las nuevas orientaciones wagnerianas), un Arte rebajado a la categoría de mero pasatiempo y, dado el carácter abstracto de nuestra existencia, regido por conceptos y desprovisto de mitos ${ }^{120}$.

Para Nietzsche la cultura $(\text { Kultur })^{121}$ de un pueblo es la "unidad del estilo artístico" en todas las manifestaciones de su vida, 
en el sentido de "unidad viva" desde su completa realidad. Por ello, la abundancia de sabios, así como la acumulación de conocimiento, no son indicios de cultura pues fácilmente los podemos encontrar en la mismísima barbarie (en cuyo caso observamos: o bien la carencia total de un estilo artístico, o bien la confusión caótica de varios de ellos). Esto precisamente le sucede al pueblo alemán; a pesar de toda su ciencia, se encuentra influenciado por diversos estilos entremezclados y en general confundidos entre sí. Además agrega Nietzsche, sólo es cuestión de que cada alemán se pregunte por el origen de sus costumbres y modales y puede observar al instante que una de las influencias más notables es la ejercida por Francia y la cultura francesa. Alemania, a pesar de haber derrotado militarmente a Francia en 1871, no puede imponerle una cultura alemana porque la perdió; aun peor, en Alemania ni siquiera hay un concepto de cultura.

Según Nietzsche, la mayoría de los alemanes, excepto una elite exclusivísima a la que pertenecen Winckelmann, Kant, Lessing, Goethe, Schiller, Hölderlin y Schopenhauer, entre otros, poseen una verdadera cultura; y en este sentido, Nietzsche acusa a Hegel, a Vischer y fundamentalmente a David Strauss, los filisteos de la educación (Bildungsphilister) ${ }^{122}$ como prefiere llamarlos, por considerarlos responsables de fomentar dicha ilusión. Al respecto, sólo la lengua y el habla, a pesar de las mezclas y modificaciones que sufren por parte de otras nacionalidades y costumbres foráneas, perduran en el tiempo mientras conservan y resguardan su espíritu germánico; en ellas pues, se depositan todas las esperanzas para el resurgimiento de la próxima cultura en el futuro ${ }^{123}$. 


\section{Acápite 4: Ante todo la vida}

El hombre moderno ya no se atreve a mostrar su verdadera personalidad y prefiere adoptar la "máscara" del hombre cultivado, del docto (Gelehrter), que es capaz de dominar sus impulsos más íntimos. Según Nietzsche esto sucede porque la personalidad del hombre se ha debilitado considerablemente; es más, en la actualidad no abundan las personalidades y menos aún las "personalidades libres" $" 124$. En este sentido, la educación que se da a los jóvenes en Alemania parte de una concepción falsa de la cultura cuya finalidad es pues el docto, el científico, el filisteo cultivado que pretende resolver los problemas de la vida mientras vive al margen de la vida plena y no se da cuenta de que lleva dentro de sí una contradicción provocada por la relación entre la Ciencia y la vida auténtica. Los alemanes creen en la "aeterna veritas" 125 de su educación y de su concepción de la cultura, de la misma manera que Platón hubiera querido que la primera generación hombres de su Estado ideal creyese en una primera "piadosa mentira". Sin embargo, los alemanes no pueden tener una cultura porque, de acuerdo con su 
educación, es imposible que la tengan y esto inevitablemente es una "piadosa verdad".

La cultura sólo puede nacer, crecer y desarrollarse en la vida, $\mathrm{y}$ vivir es algo que hay que aprender, reaprender y ejercitar continuamente. Los alemanes estudian la cultura pero sin relacionarla con la vida; hacen Ciencia de la cultura precisamente en forma de Ciencia Histórica pero con sólo recorrer la Historia no se puede aprehender la conclusión vital del pasado. Por lo tanto, es necesario vivir la vida, esa fuerza obscura, impulsiva e inaccesible que se desea a sí misma ${ }^{126}$ mientras resulta inevitable sentir además el auténtico peligro de vivir; ésta es la única manera mediante la cual puede pretenderse alcanzar la armonía entre la vida y el pensamiento para que la cultura resulte ser una liberación ${ }^{127}$. En definitiva, la vida es la fuerza superior que domina al conocimiento y a la Ciencia. El exceso de estudios históricos, en cambio, debilita esa fuerza. El conocimiento presupone la vida, con lo cual tiene un profundo interés en conservarla ${ }^{128}$; pero, si en esta contienda el conocimiento se encamina hacia la destrucción de la vida, corre el riesgo de destruir todo lo que se encuentra a su alrededor y de destruirse a sí mismo también. 


\section{Acápite 5: \\ Primera generación}

La primera generación (erste Generation) debe ser educada en aquella piadosa verdad a la que hicimos referencia más atrás. Ella le ayudará a sobrellevar los nuevos padecimientos, pues a partir de tal verdad esta élite tendrá que educarse a sí misma pero también contra sí misma. Y tal vez se repita una y otra vez la frase en castellano antiguo: "Defiendame Dios de my" salve a la Humanidad de la cultura inculcada y aprehendida, a partir de lo cual probablemente intente adquirir una nueva cultura y con ella nuevas costumbres. De esta manera, cada individuo debe autosuperarse para luego poder pronunciar un juicio sobre sí mismo, que se tolera sin dificultad si se refiere a una época en términos generales.

Los alemanes no tienen educación, no han aprendido a vivir y ni siquiera tienen una cultura propia. Tal vez la vida sea un presupuesto para decir "cogito ergo sum" pero eso no garantiza una vida completa y lozana (volle und grüne Leben). En el futuro, estos hombres liberarán la vida que hasta ahora han llevado oculta y lo 
harán en el momento en que logren desencadenar la fuerza de su propia juventud (Jugend). Sin embargo, agrega Nietzsche, esa vida padece un serio mal provocado por exceso de estudios históricos: es la enfermedad histórica (historischen Krankheit). Y los antídotos para todo lo histórico son: lo no-histórico (Unhistorische), es decir, el Arte y la capacidad de poder olvidar para poder vivir; y lo suprahistórico (Überhistorische), aquello que da a la existencia el carácter de eternidad e identidad, como por ejemplo, el Arte y la Religión. Estos son pues los antídotos para un veneno que no es otra cosa que la Ciencia, cuyo método científico se arroga el derecho de establecer qué es verdadero y qué es justo ${ }^{130}$.

En consecuencia, la misión de esta nueva juventud, de esta primera raza de luchadores y matadores de dragones (ersten Geschlechtes von Kämpfern un Schlangentötern), que anhela una formación y una Humanidad más bellas y felices consiste en sacudir (erschüttern) las nociones de salud (Gesundheit) y formación (Bildung) para engendrar (erzeugen) el escarnio (Hohn) y el odio $(H a \beta)$ contra estas híbridas monstruosidades de nociones (hybride Begriffs-Ungeheuer). Estos hombres jóvenes, con salud más vigorosa (kräfttigeren Gesundheit) para determinar su propia naturaleza, no pueden valerse de ninguna concepción u orientación partidaria sino que sólo se persuaden a través de su propio poder activo, combativo, de resolución y ejecución (tätigen, kämpfenden, ausscheidenden, zerteilenden Macht), a la vez que ostentan un sentimiento de vida (Lebensgefühle) creciente. Probablemente muestren rudeza (Roheit) y desmesura (Unmãßigkeit) porque todavía no son bastante maduros y sabios para contenerse. Saben, en cambio, que poseen una naturaleza más natural (natürlicheren Natur) que la de sus predecesores, los adultos y los ancianos cultos del presente ya que pueden disfrutar de todos los consuelos, privilegios y licencias de la juventud, en particular del privilegio de la lealtad más valerosa e imprudente (Vorrecht der tapferen, unbesonnenen Ehrlichkeit) y del 
consuelo entusiasta de la esperanza (begeisternden Trost der Hoffnung ${ }^{131}$.

Sin embargo, una parte de la sociedad espera su curación y su liberación de la "enfermedad histórica" para que, una vez restablecida y en situación de poder continuar la Historia, pueda servirse del pasado desde tres puntos de vista diferentes. A saber: Historia monumental (monumental), que relata los sucesos a expensas de las causas y efectos como monumentos dignos de ser admirados; Historia anticuaria (antiquarisch), que honra el pasado y repudia lo nuevo; e Historia crítica (kritisch), que tiene la capacidad de juzgar y condenar. En ese momento, serán más ignorantes que toda la "intelectualidad" del presente, pues tendrán que olvidar gran parte de su saber, y ya no habrá interés en observar lo que tradicionalmente se considera objeto de curiosidad; en ese sentido, será notoria su incultura (Unbildung), su frialdad (Gleichgültigkeit), y su reserva (Verschlossenheit) para con algunas cosas consideradas "célebres" y otras definidas como "buenas". En otras palabras, en esa etapa de su curación dejarán de ser agregados antropomórficos (menschenähnliche Aggregate) para convertirse, nada más ni nada menos, en auténticos y verdaderos hombres ${ }^{132}$.

Paralelamente y durante varios siglos, los griegos se vieron expuestos al peligro de perecer a causa de contiendas contra extranjeros y por la influencia del pasado, es decir, por la Historia. Pero paulatinamente se vuelven autoconscientes, aprenden a "organizar el caos" y de acuerdo con la doctrina délfica comienzan a recordarse a sí mismos, es decir, a reconocer sus auténticas necesidades para dejar de lado lo meramente aparente. Según Nietzsche, los alemanes padecen esos mismos peligros; de manera que, si observan con atención la cultura helénica, tal vez encuentren en ella un claro reflejo que sirva a modo de ejemplo para su salvación. 
Cada uno tiene que organizar el caos que lleva dentro de sí y volver sobre sí mismo para atender aquellas necesidades que son genuinamente propias. Ya no hay lugar para la complacencia en el mero imitar. Y aquí está el fundamento para comprender que la cultura es algo más que una "decoración de la vida", es decir, algo más que un burdo engaño, "pues todo adorno oculta lo que adorna"133. 


\section{Acápite 6: Genio}

De acuerdo con Nietzsche, de las tres imágenes del Hombre $^{134}$ glorificadas sucesivamente en su época, el "hombre de Schopenhauer" es el que asume el sufrimiento voluntario por la verdad. Con ello anula su propia voluntad y se prepara para una transformación completa de su ser, cuya meta es el sentido auténtico de la vida. El hombre veraz (Wahrhaftige) confiere a su actividad un sentido metafísico, que puede ser explicado por leyes de una vida superior (höhern Lebens), y afirmativa, aunque parezca un destructor y quebrantador de las leyes de esta vida. Es un hombre que por sus conocimientos se encuentra muy alejado del hombre científico y que no duda en dedicar su vida a la auténtica verdad. En gran medida padece penosos sufrimientos, pero del dolor nace su búsqueda de la verdad $^{135}$. Por su valentía (Tapferkeit), es capaz hasta de destruir su propia felicidad y puede verse en la obligación de oponerse, incluso, a quienes ama y a todas las instituciones. Se muestra hostil, aunque con esto también sufre y a pesar de su afán de justicia (Streben nach Gerechtigkeit), parece injusto (ungerecht) por poner en sus 
apreciaciones la distintiva medida del Hombre. De todos modos, se anima a evocar palabras semejantes a las que usa Schopenhauer, el gran educador: "una vida feliz es imposible: lo más elevado, que el hombre puede lograr, es una vida heroica"136.

Quien vive de esa manera, no lo hace sólo para sí mismo, lo hace también para los demás aunque sea poco o mal recompensado, pues resulta tan difícil castigarlo como premiarlo; y llegará el momento en que será reconocido por haber puesto en claro todo lo que estaba obscuro. Por ahora tiene que llegar al fondo de la existencia y, consecuentemente, tiene que tratar de responder a las siguientes preguntas: “¿Por qué vivo? ¿Qué lección debo aprender de la vida? ¿Cómo he venido a ser lo que soy y porqué sufro entonces con este ser-asi?"137. El heroísmo de la veracidad (Heroismus der Wahrhaftigkeit) consiste en dejar de ser un juguete de una época; para lo cual, es decir, para desentrañar los enigmas correspondientes hay que sumergirse en los abismos del ser, en el "ser así y no otro", en lo imperecedero. El hombre heroico (heroische Mensch) desprecia tanto su bienestar como su malestar, sus virtudes y sus vicios; y en general, todas las cosas, ya que su fuerza reside pues en el "propio olvido de sí mismo"138.

Y por estos años Nietzsche también se pregunta: "¿Dónde

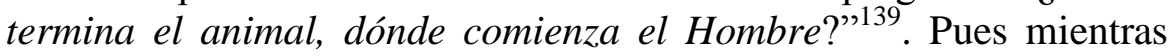
éste aspira a la vida como a la prosperidad, aun no se eleva de la simple animalidad, a menos que quiera conscientemente lo que el animal quiere ciegamente. Eso pues, nos sucede durante la mayor parte de nuestra vida: no logramos diferenciarnos cabalmente del resto de los animales, pues somos criaturas cuya vida y sufrimientos parecen carecer de sentido. Entonces advertimos que existen hombres verdaderos (wahrhaften "Menschen") que pueden elevar nuestra vida, como son los filósofos, los artistas y los santos (die Philosophen, Künstler und Heiligen). Con y por su aparición la 
Naturaleza llega a su fin y, en tal caso, resulta comprensible el olvido de los fines en la vida y en el devenir ${ }^{140}$.

Llega el momento de descubrir una nueva esfera de deberes que, al cumplirlos, nos hace formar parte de una poderosa comunidad (mächtige Gemeinsamkeit) cuyos miembros coinciden en un mismo propósito fundamental: "la cultura" que asimismo nos sitúa frente a una sola tarea: "Promover en nosotros y fuera de nosotros la procreación del filósofo, el artista y el santo, y de ese modo trabajar en la perfección de la Naturaleza"141.

Según Nietzsche, el fin de la evolución tiene lugar cuando una especie alcanza su límite extremo y forma el tipo intermedio que conduce a una especie superior; y no, en cambio, cuando la especie muestra una cantidad abundante de individuos semejantes que gozan del mayor bienestar, o cuando son los últimos que llegan a esa categoría.

Podemos decir entonces que en toda la Naturaleza sólo importan los ejemplares superiores (höhere Exemplar), los más extraordinarios (ungewöhnlichere), los más poderosos (mächtigere), los más complicados (kompliziertere) y los más fecundos (fruchtbarere). Y de esta manera, cuando la Humanidad se torna consciente de su fin, tiene entonces el deber de establecer y buscar las condiciones necesarias y más favorables para la procreación de los grandes redentores. En consecuencia, la vida del individuo adquiere su mayor valor y su más profundo significado cuando vive a favor de los ejemplares más raros y más valiosos (seltensten und wertvollsten Exemplare); no así, cuando lo hace a favor de los más numerosos o, en otras palabras, de los menos meritorios ${ }^{142}$.

Con esta sólida y profunda intención, agrega Nietzsche, nos situamos en el círculo de la "cultura" (Kreis der "Kultur"); y sólo aquel que se entrega enteramente a los grandes hombres (großen Menschen) recibe la "primera consagración de la cultura" (erste Weihe der Kultur) cuyos signos son: vergüenza de sí mismo 
(Selbstbeschämung), odio hacia la propia estrechez (eigne Enge), presentimiento (Vorgefühl) de todos los que están por venir y luchan (Werdenden und Käpfenden), convicción (Uberzeugung) de encontrar casi en todas partes la miseria (Not) de la Naturaleza y, por último, compasión (Mitleiden) por el genio (Genius) ${ }^{143}$. En cuanto al efecto de la "segunda consagración de la cultura", no exige sólo la evaluación del mundo exterior sino además un acto determinado: la lucha por la cultura, contra todas la influencias, contra todas las costumbres, contra todas las leyes e instituciones que no son capaces de reconocer su único fin: la procreación del genio.

En todas las épocas, los genios y los doctos se ven enfrentados; estos últimos destruyen la Naturaleza para analizarla y entenderla, mientras que los primeros sólo quieren una nueva Naturaleza. Lamentablemente, denuncia Nietzsche, los esfuerzos de la educación están destinados solamente a producir doctos, empleados estatales, comerciantes, filisteos de la educación, o bien, el producto de la mezcla de todos ellos ${ }^{144}$. 


\title{
PARTE III
}

\section{Segundo período}

\section{Introito}

\begin{abstract}
One cried, 'God bless us', and 'Amen' the other, As they had seen me with these hangman's hands.

List'ning their fear, I could not say 'Amen' When they did say 'God bless us!' 145
\end{abstract}

A partir de 1876 observamos una nueva fase en el pensamiento de Nietzsche. En estos años la enfermedad se apodera de él; necesita tratamiento médico, dietas especiales y agotadoras caminatas para mitigar los dolores de vientre. Por ello, introduce un estilo literario más acorde con su deteriorada capacidad para retener y continuar el desarrollo de sus ideas. Estamos hablando pues del uso de aforismos.

$\mathrm{Su}$ meta consiste ahora en la investigación de las cuestiones humanas, quizá demasiado humanas, pero tan sólo humanas. Aún son años de cátedra en Basilea, de viajes y breves estadías en los siguientes lugares: Bayreuth, Basilea, Génova, Nápoles, Sorrento, Rosenlaui, Alta Engadina, Naumburg, Riva, Venecia, Marienbad, Stresa, Recoaro, Messina, Grünewal, Berlin, y Tautemburg. Es decir que Nietzsche vaga permanentemente; se dirige hacia el mar y las 
montañas, muchas veces sólo en compañía de su sombra, en busca de la catarsis o de una mueva aurora. Lo importante ya no es "el qué", la Metafísica, sino "el cómo", las Ciencias Naturales, o incluso aquello que Nietzsche hubiera preferido fundar, una Ciencia alegre.

Es una época de amores y desengaños, en la que el fulgor de la pasión por la inalcanzable sanpeterburguesa Lou Andreas-Salomé (Луиза Густавовна Саломе) le hace ver más de lo que sus debilitados ojos le permiten. A partir de estos años deja de reconocer en Wagner al músico por considerarlo ahora un actor, más precisamente, un comediante. El período se extiende hasta el 26 de Agosto de 1882, fecha de publicación de La Gaya Ciencia (Die Fröhliche Wissenschaft). Es el momento de proclamar una moral que esté más allá de las concepciones judeo-cristianas tradicionales del bien y del mal, preanunciar la llegada de Zaratustra y arriar las banderas de todos los fanatismos, en particular según Nietzsche, la que hizo posible el "credo quia absurdum est" $"$ ". 


\section{Acápite 1: Espíritu científico}

Según Nietzsche, la teleología está basada en concepciones que presuponen la eternidad del Hombre, pero todas las cosas sin excepción evolucionan; por lo tanto no hay, porque no puede haber, fenómenos eternos ni "hechos eternos", de la misma manera que tampoco puede haber "verdades absolutas" 147 . La suma total de descubrimientos realizados y colmados de consecuencias para el conocimiento hasta ahora es lo más elevado; aceptarlo incondicionalmente demuestra valor y sobre todo honradez. Sólo por esta actitud, cuando la Humanidad deja de creer en la inspiración y comunicación milagrosa de las verdades, da un salto fundamental hacia una nueva Humanidad. Por ello, una cultura superior (höheren Kultur) únicamente puede tener en cuenta a aquellas verdades encontradas mediante un estricto método que no deje lugar a dudas; la actividad de una cultura inferior (niederen Kultur) en cambio, consiste en elaborar símbolos y formas esmeradamente acabadas, como vemos en las épocas metafísicas y artísticas ${ }^{148}$. Aquí reside la importancia del lenguaje para el desarrollo de la civilización, pues el 
Hombre al crear nuevas palabras no solamente da denominaciones a las cosas, sino que además cree expresar mediante ellas su verdadero fundamento, es decir, su esencia. Indudablemente, el lenguaje es el primer paso en el camino hacia el desarrollo de la Ciencia ${ }^{149}$.

Posteriormente, la Ciencia en su constante progreso suprime poco a poco todos los excesos irracionales del "pensamiento ilógico" para celebrar su mayor triunfo en una "Historia de la génesis del pensamiento" y permitirnos llegar probablemente a 1a siguiente conclusión: lo que llamarnos mundo (Welt) es el resultado de un conjunto de errores y fantasías reunidas y mejoradas pacientemente, originadas a lo largo de la evolución de los seres organizados en grupos y comunidades, para llegar hasta nosotros a través de una incuestionable y sagrada herencia.

Desde el principio, el hombre observa el mundo desde un punto de vista religioso, moral, estético, pero lo hace tan ciegamente que transporta a las "cosas", y luego deja impregnado en ellas, un tinte de "apariencias", con lo cual permanecen coloreadas de manera permanente de la misma manera que todas sus concepciones fundamentales. ${ }^{150}$. En este sentido, las ideas metafísicas sostienen la creencia que en ellas están dadas las bases sobre las cuales hay que ordenar todo el porvenir de la Humanidad ${ }^{151}$. Por lo tanto, podemos entonces elegir las características y los hábitos de una moralidad superior (höheren Sittlichkeit) que tarde o temprano pueda cumplir con su propósito, a saber: la destrucción de todas las moralidades inferiores (niedrigeren Sittlichkeit). Y mientras que en la antiguiedad el Hombre vive instintiva y azarosamente, en la actualidad con plena conciencia puede tomar la responsabilidad de empezar a desarrollarse con la intención de fundar una nueva civilización ${ }^{152}$.

En consecuencia, los grandes espíritus del porvenir tienen como propósito alcanzar un "conocimiento de las condiciones de la cultura", a fin de establecer el rumbo hacia dónde puede dirigirse la nueva Humanidad ${ }^{153}$. Sin embargo, desde el punto de vista de 
Nietzsche, la teoría de Schopenhauer muestra que todavía el espíritu científico es notablemente débil, pues lo que en ella predomina es la antigua y conservadora "necesidad metafísica" ". De todas maneras, para que la abundancia desmedida de sentimientos provocados por el cristianismo, por los filósofos, por los poetas y por los músicos no invada completamente la cultura, tenemos que evocar con frecuencia al espíritu de la Ciencia (Geist der Wissenschaft) con su frialdad y su escepticismo ${ }^{155}$.

En la actualidad, la semiciencia puede ser tan poderosa como la Ciencia, pues ve las cosas con liviandad y hace sus opiniones comprensibles y convincentes ${ }^{156}$ para todos. Pero el Hombre se conoce por completo a sí mismo sólo cuando conoce todas las cosas, ya que éstas son sólo los límites de aquél. Por lo tanto, toda la Ciencia está encerrada en la máxima que dice: "Conócete a $t i$ mismo" ${ }^{" 157}$, porque a través de ella conocerás a los hombres y a los dioses. 


\section{Acápite 2: Libre albedrío}

Para Nietzsche, las conductas del Hombre siempre están orientadas hacia el valor del fin; por eso, no hay comportamientos a favor o en contra de alguna cosa sin otros sentimientos que no sean los de querer lo provechoso y evitar lo perjudicial ${ }^{158}$. La historia de los denominados "sentimientos morales", en virtud de los cuales nos hacemos responsables, comprende las siguientes fases: en primer lugar, se designan acciones aisladas llamadas buenas o malas sólo de acuerdo con las consecuencias útiles o nocivas que ocasionan a una comunidad dada. Con el transcurrir del tiempo, se olvida el origen de esas designaciones y después llegamos a creer que las mismas acciones independientemente de sus consecuencias poseen la cualidad de "buenas" o "malas", es decir, no hacemos otra cosa que tomar la consecuencia por la causa. Luego, unimos estas cualidades (bueno/malo) a las intenciones $\mathrm{y}$, posteriormente, realizamos una proyección desmedida, pues, otorgamos el atributo de bueno o malo no a las intenciones aisladas sino al ser íntegro de un hombre concreto. Así hacemos responsable al Hombre de su influencia, luego 
de sus actos, posteriormente de sus intenciones y en definitiva de su ser. Pero el Hombre no es responsable de sus actos y no puede serlo porque sólo es una consecuencia necesaria, determinada por las influencias del pasado y del presente.

Reconocemos entonces que la historia de los sentimientos morales es asimismo la historia del error de la responsabilidad y esto se debe, según Nietzsche, a que descansa en otro error: el de la "libertad de la voluntad". Y no porque el Hombre sea libre sino que, por considerarse libre, siente primero el remordimiento y luego la necesidad del arrepentimiento. El grado de malestar es relativo a quien lo padece y así como nos familiarizamos y habituamos a las costumbres, podemos también desacostumbrarnos. Esto es algo variable pero inseparable del desarrollo de la moral y de la civilización. Por ello, y desde este punto de vista, el solo hecho de juzgar equivale también, y al mismo tiempo, a ser injusto ${ }^{159}$. 


\section{Acápite 3: \\ El bien \& el mal}

La Moral (Moral) es simplemente una "mentira necesaria" para evitar sentirnos avergonzados y humillados frente a nuestros propios actos, con lo cual el Hombre deja el estadio del animal para ingresar al del superanimal (Uber-Tier) ${ }^{160}$. Desde un principio establecemos la jerarquía de "bienes" y de "males", a partir de lo cual podemos determinar si una conducta es moral o inmoral. Así como esta jerarquía varía a lo largo de la Historia, también varían las moralidades, porque el fundamento del bien y del mal no es la moral sino que por el contrario, primero establecemos qué conductas están bien y por antonimia cuáles están mal. Finalmente, podemos distinguir una acción moral de una que es considerada inmoral ${ }^{161}$.

En cuanto al origen de los conceptos "bien" y "mal" tenemos que buscarlo en el espíritu de las razas y castas dirigentes. Los buenos pertenecen a la comunidad de los fuertes con un claro sentimiento de solidaridad y fraternidad, pues todos los integrantes están unidos por el sentimiento de la represalia; los malos, en cambio, son sólo un grupo de hombres sometidos e incapaces que 
carecen de sentimientos de unidad. Por eso, los buenos suelen ser una casta y los malos, apenas una masa informe.

Además, según Nietzsche, hay una interesante relación que la Historia se encarga de atestiguar: aquellos que tienen el poder de devolver el bien por el bien y el mal por el mal, son los buenos; los que no pueden hacer esto, sencillamente son los malos. Así los buenos son los nobles, los amos; y los malos, los villanos, los esclavos ${ }^{162}$. Unos son los vencedores y los otros los vencidos. Pero sólo los buenos establecen qué es moral y qué es inmoral, como también qué es justo y qué es injusto ${ }^{163}$. Ambos piensan y se comportan de maneras distintas porque ambos tienen diferentes moralidades.

Poco a poco el Hombre establece y restablece cuáles son las acciones beneficiosas y cuáles son las honorables, En este caso, la Ciencia le permite advertir qué es lo más útil para el mayor número de individuos, con lo cual puede separar la utilidad general de 1a personal; es decir, puede obrar como un individuo-colectivo ${ }^{164}$. Por esto mismo, opina Nietzsche, hacer de sí mismo una persona completa y proponerse en todos sus actos el "bien más grande" va más allá que las caritativas acciones en favor de los demás ${ }^{165}$.

Por lo tanto, ser moral quiere decir: acatar una ley o adherir a una tradición. Llamamos "bueno" a quien por naturaleza y a consecuencia de una larga herencia actúa fácil y gustosamente de acuerdo con la moral. Asimismo, ser "malo" quiere decir ser inmoral, practicar la inmoralidad o, dicho en otras palabras, oponerse a las costumbres y tender a emanciparse de las normas tradicionales. Esta tradición se ha formado sin tener en cuenta algún imperativo inmanente y categórico; se ha hecho en virtud de 1a conservación de una comunidad, de un pueblo. Seguirla es moral, mientras que emanciparse de ella en cambio, es peligroso no tanto para e1 individuo sino para la comunidad, porque atenta contra el orden 
establecido $^{166}$ y 10 que podemos considerar como la única posibilidad de bienestar ${ }^{167}$.

Por otro lado, las malas acciones que en la actualidad nos indignan se basan en la creencia en que quien las comete goza de libre arbitrio y por lo tanto, podría no haberlas realizado. Sin embargo, continúa Nietzsche, las malas acciones son motivadas en el individuo por el instinto de conservación, más precisamente por la aspiración al placer y por el deseo de rehuir el dolor.

Además, para poder establecer las bases de la moralidad, el individuo más poderoso o un individuo-colectivo, por ejemplo, la sociedad o el Estado, tiene que sacar a los individuos de su aislamiento, más tarde agruparlos y por último someterlos. La moralidad aparece después de la coacción (Zwang); luego se convierte en costumbre, después en libre obediencia y al final en impulso socialmente natural. Posteriormente -dado que lo habitual y cotidiano con el correr del tiempo resulta ser placentero- adquiere el nombre de virtud (Tugend) ${ }^{168}$. Ahora bien, lo provechoso para los hombres exige su mantenimiento; pero sanciones y recompensas, así como censuras y elogios, obran directamente sobre la vanidad; en consecuencia, lo provechoso mismo va unido al mantenimiento de la vanidad $^{169}$. Por esta razón, si desaparece el uso del método de premios y castigos, probablemente desaparezcan también los motivos que nos conducen a realizar algunas acciones y evitar otras.

Entre las acciones buenas y malas no hay diferencias de especie (Gattung) sino sólo de grado (Grades). Vemos entonces que todas las opiniones al respecto pierden su valor y su grado de verdad, ya que los sentimientos que llevan a los hombres a alabar al santo o glorificar al héroe, aparecen ahora como simples errores pues no tiene sentido enaltecer o censurar a aquello que se presenta como natural y necesario. $\mathrm{Y}$ en este caso, muchas acciones aparecen definidas como malas pero denotan una gran cuota de necedad 
oculta, porque el nivel de inteligencia de quien las juzga no suele ser muy alto.

En definitiva, comienza a brillar un nuevo evangelio (nеuen Evangeliums); todo es necesidad y así lo proclama el nuevo conocimiento (neue Erkenntnis). Todo el dominio de la moral está en un constante fluir; "más 'todo aun está en curso': hacia 'un' fin"170. Bajo la influencia del conocimiento en aumento, disminuyen todos los errores de estimación, de amor, de odio, y se arraiga pues el hábito de comprender, de no amar, de no odiar, de ver desde arriba, para dar lugar al sabio (weisen) del mañana, al individuo inocente pero consciente de su inocencia (unschuldbewußten), a diferencia de lo que vemos hoy, ya que en la actualidad se sostiene y mantiene al no sabio (unweisen), al injusto y consciente de su culpabilidad.

La moralidad es, pues, el sentimiento conjunto de las costumbres que orientan la vida y la educación de los individuos, en tanto miembros de un todo o de una mayoría dentro la sociedad; por eso tal vez, resulte más sublime e incluso hasta más útil "mirar más allá" de las consecuencias inmediatas para el prójimo y fijar de esta manera fines últimos más lejanos, diferentes de los originados en el temor, la costumbre y la igualdad, independientemente de la certeza de que 1a libertad de espíritu de algunos comienza por depositar la duda, el pesar -o algo aún peor- en los demás.

E1 impulso que predomina, tanto en los hombres más comunes (gemeinsten Menschen) como en los más elevados (höchsten), es el impulso por conservar la especie que se manifiesta a su vez a modo de razón o pasión espiritual y, al aparecer, rodeado de argumentos con fundamentos, pretende hacernos olvidar que sólo es instinto y locura ${ }^{171}$; en ese sentido, dice Nietzsche, la naturaleza superior (höheren Natur) se torna aun más antirracional (unvernünftigere) cuando su propia razón, luego de hacer una pausa, sucumbe a sus impulsos más íntimos ${ }^{172}$. 
Hace falta, pues, establecer una "nueva justicia" y promover a los "nuevos filósofos", instaurar relaciones sociales más razonables y organizar una mejor manera de vivir, porque el campo de la moral no es plano, en todo caso es esférico; y por lo tanto, la moral como la tierra igualmente tiene sus antípodas. No hay un solo mundo, y descubrir otros es tarea de los filósofos.

Todas las morales que recomiendan la realización reiterada de las actividades, para poder llegar a hacerlas de la mejor manera posible, de modo tal de ser uno mismo el único capaz de cumplirla, son mucho más elevadas y recomendables ${ }^{173}$; en este sentido, el talento es el nombre que damos a estudios anteriores, a experiencias que tal vez se remontan al tiempo de nuestros padres o antepasados. Quien aprende "se dota a sí mismo" de talento, aunque no sólo es cuestión de voluntad; se requiere pues la capacidad para poder aprender ${ }^{174}$. 


\section{Acápite 4:}

\section{Naturalezas fuertes \& naturalezas débiles}

Como corolario de lo dicho anteriormente, la Historia confirma que una raza se conserva mejor cuando los individuos, a lo largo de las sucesivas generaciones, muestran un vivo altruismo (Gemeinsinn) como resultado de la creencia común en principios indiscutibles y su posterior práctica estricta. Sin embargo, según Nietzsche, las comunidades fundadas en individuos de rasgos similares, y cuya herencia no hace más que acentuar la estabilidad de sus características, corren el riesgo de embrutecerse porque sólo aquellos que son independientes (ungebundeneren), más inseguros (viel unsichereren) y débiles moralmente (moralisch-schwächeren), posibilitan el progreso intelectual (geistige Fortschreiten), pues son capaces de probar toda clase de ocurrencias y novedades.

Muchos de estos hombres debido a su debilidad, viven sin ejercer influencias; en cambio, algunos pocos pero los suficientes, sacuden y -ocasionalmente- alteran la estabilidad de la comunidad, con lo cual se "inocula" algo nuevo al ser colectivo. En este sentido, si ha de producirse un progreso, las naturalezas degenerantes 
Ricardo Torres Medrano

(abartenden Naturen) cumplen un rol cuyo significado resulta ser fundamental. Por lo tanto, las naturalezas más fuertes (stärksten Naturen) conservan lo que Nietzsche denomina el tipo "fijo", mientras que las débiles (schwächeren) ayudan al resto de las razas a perfeccionarse (fortbilden), no tan sólo por ser distintas sino por ser más delicadas ${ }^{175}$. 


\section{Acápite 5:}

\section{Cultura superior \& cultura inferior}

Un grado elevado de cultura se logra cuando se superan las nociones y angustias supersticiosas, religiosas y metafísicas en general; entonces, es importante efectuar un movimiento retrógrado (rücklãufige Bewegung) para observar en esas representaciones su justificación histórica y psicológica y poder alcanzar de esta manera una verdadera "conciencia cósmica". Tal vez por eso, echar una mirada atrás con porte de superioridad sobre la metafísica sea el primer paso ${ }^{176} ; \mathrm{y}$ así como los hombres pequeños (geringeren Menschen) atraviesan las fases de la evolución como si éstas no existieran, una señal de cultura superior (überlegener Kultur) consiste en tener plena conciencia de todas ellas ${ }^{177}$. En otras palabras, el Hombre debe poseer la capacidad de separar sin confusión alguna lo que es Ciencia de aquello que no lo es, para poder mantener de esta manera su salud mental; porque si no logra diferenciarlas y todo gira en torno a las ilusiones, las opiniones parciales y las pasiones, Nietzsche anuncia que nuestra cultura podría estremecerse, violentarse y finalmente crear las condiciones para 
presenciar en primer lugar la ruina de las Ciencias y posteriormente el retorno a la barbarie ${ }^{178}$.

Por otro lado, el tema de la religión está completamente agotado; "Dios está muerto"179, pero todavía hay tumbas, monumentos, iglesias, en donde se muestra y venera su imagen o lo que queda de ella: su sombra. Es preciso despojar a la Naturaleza de sus atributos supuestamente divinos y asumir entonces nuestro rol de hombres naturales ${ }^{180}$.

Dios ha muerto (tot) hace mucho tiempo pero no hay que olvidar que hemos sido nosotros quienes le hemos dado muerte, día tras día, durante casi dos mil años ${ }^{181}$; por eso, lo que escuchamos en nuestra conciencia no es la voz de Dios sino solamente la voz de algunos hombres, de algún hombre o en todo caso, nuestra propia voz $^{182}$. Ha llegado el momento de decir: "líbrame Dios de dios" "183. Y en este sentido, continúa Nietzsche, hay hombres que no quieren mirar hacia la luz porque significa reconocer también la existencia de esa sombra; e incluso permanecerían en esa actitud aun cuando sólo hubiese luz y ya no sombra. 


\section{Acápite 6: Vivir peligrosamente}

El Hombre que quiera liberarse de las trabas ordinarias de la vida, con el solo fin de conocer cada día más y mejor, debe renunciar a muchas cosas, o a casi todo de lo que tiene importancia para los demás; debe sentirse como en la situación más deseable y pronto, con intrepidez, estará por encima de los hombres, las costumbres, las leyes y las opiniones cotidianas ${ }^{184}$.

Algunos trabajan a modo de funcionarios, de comerciantes, de eruditos, es decir, de representantes de algo pero no como hombres íntegros, autodeterminados, aislados y únicos ${ }^{185}$. Quien quiera sinceramente ser libre tiene que perder la inclinación hacia las faltas y los vicios; tampoco tiene que sentir enfado o desazón porque ahora su voluntad sólo desea "el conocer y su medio para ello", es decir, alcanzar el estado permanente y más propicio para conocer ${ }^{186}$, aunque los doctos se avergüencen del "ocio". En este sentido, de acuerdo con Nietzsche, si la ociosidad es el origen de todos los vicios, se encuentra también muy cerca de ser la causa de todas las virtudes $^{187}$. Hay que hacer pues un viaje retrospectivo para seguir los 
pasos de la Humanidad en su marcha a través del pasado y aprender así en qué dirección ya no podemos avanzar; y al tratar de desentrañar los misterios del porvenir, la propia vida toma el valor de un medio de conocimiento. De cada uno de nosotros depende que todos los aciertos y fracasos sirvan para un propósito, es decir, lleguen a ser una "cadena necesaria de anillos de cultura", a partir de la cual podamos inferir entonces el curso necesario de la civilización. Por eso, “... sírvete a ti mismo como fuente de experiencia"188 y luego no habrá impulso más noble que la actitud de dar sin esperar algo a cambio ${ }^{189}$.

Vivir es un constante imaginar ${ }^{190}$ y nada nos prohíbe vivir con la idea de volver a vivir; podemos imprimir en nuestra vida además, el sello de la eternidad, lo cual nos garantiza la perdurabilidad. Pero sólo será inmortal aquel que quiera de manera sincera repetirse eternamente, y esto vale mucho más que cualquier apreciación de las religiones que desprecian la vida material.

Además, vivir significa ser firme y decidido contra todo lo que en nosotros, y en los demás, produce debilidad y envejecimiento ${ }^{191}$ porque la vida tiene que ser únicamente entendida como un medio para el conocimiento permanente ${ }^{192}$. "Sum, ergo cogito: cogito ergo sum" "193; es preciso vivir sin dejar de pensar en las palabras que la conciencia suele susurrar: "Tú debes llegar a ser el que eres" ${ }^{\prime 194}$, sea cual fuere el precio a pagar; e incluso, si el riesgo consiste en correr los mayores peligros, mejor aún. Solamente cuando uno está a punto de perder la propia vida se experimenta quizá la manera más fascinante para saber que aún se vive; en ese preciso instante, la vida cobra su mayor valor, su máxima intensidad. Y ahí está según Nietzsche el secreto para tener una existencia fecunda y una vida placentera: "iVivir peligrosamente!" (“'igefährlich leben!”) 195 . 


\section{Acápite 7: \\ Espíritu libre}

El espíritu libre (Freigeist) piensa de una manera distinta de lo que podría esperarse de acuerdo a su procedencia, su ambiente, su posición o en función de las opiniones dominantes de su tiempo. Por eso, el espíritu libre siempre es la excepción, mientras que los espíritus cautivos (gebundenen Geister) son la regla; desde el punto de vista de éstos últimos, aquéllos no han de terminar sino en acciones condenables e incompatibles con la moral o en todo caso, en excesos debido al origen incierto de sus principios. Y ése es otro problema.

Algo distinto es el reconocimiento de la verdad, para lo cual sólo importa la verdad que se tiene, independientemente de los estímulos que han obrado y de las vías empleadas para descubrirla. Igualmente, lo más importante en la naturaleza de1 espíritu libre no reside en tener opiniones justas, sino en haberse desligado de lo convencional; de esta manera, lleva en sí mismo el "espíritu de la investigación de la verdad" ya que "...él exige razones, los otros, creencias" ${ }^{\prime 196}$. Al final, el espíritu libre abriga la verdad y haber 
vivido en el error es para él un beneficioso recuerdo; los espíritus cautivos en cambio proclaman el error y haber muerto por la verdad será para ellos sólo una vaporosa y narcóticamente opiácea ilusión. De todos modos aquél es muy débil, especialmente en la acción, pues conoce muchísimos motivos y criterios; mientras que éstos no necesitan razonar su comportamiento pues su tradición y su moral prescriben su conducta y por lo tanto también su vida ${ }^{197}$.

Los hombres que tienen intenciones de ser libres muestran en su manera de vivir y de pensar un "heroísmo refinado" pues sienten vergüenza de ofrecerse al respeto de las masas; su único afán, su auténtico y profundo deseo, consiste únicamente en sumergirse con todas sus fuerzas en el "ámbito del conocimiento"198. El espíritu libre odia todos los hábitos, las reglas y todo aquello que se muestra como si fuese duradero y definitivo; tiene que aprender a amar aquello que una vez odió y a odiar lo que una vez amó ${ }^{199}$. En ese caso, como los demás están habituados a no calificar a una persona según sus intenciones y virtudes sino en base a lo que en ella ven de extraño, tal vez lo consideren de manera equivocada el peor enemigo del librepensador, y lo llamen con total desprecio "pesimista del intelecto" porque el hombre auténticamente libre de espíritu piensa también sin reparos, respecto del espíritu mismo y no oculta lo horrendo que hay en las fuentes y direcciones de la cultura ${ }^{200}$; no obstante, son hombres completos (vollkommene Menschen) pues siempre obran orientados hacia aquello que es auténticamente bueno, es decir, hacia el sumo Bien ${ }^{201}$.

Además, un espíritu libre no puede adoptar otro punto de vista con respecto al Cristianismo que no sea el crítico ${ }^{202}$, de lo contrario no se encuentra, según Nietzsche, encaminado hacia la más alta libertad espiritual e individual. Por lo tanto, tiene que satisfacer todas sus necesidades aunque al principio resulte ser de una manera imperfecta. Del mismo modo, los espíritus más malos (bösesten Geister) y más fuertes (stärksten) hacen progresar a la Humanidad 
pues encienden las pasiones adormecidas, despiertan nuevamente el sentido de la comparación, de la oposición, de la diferencia y hasta el placer por lo desconocido; de igual forma, enfrentan opiniones a las opiniones, e ideales a 1os ideales, ya sea por las armas, por la transgresión de las normas, por la utilización de razones contra la fe o por el establecimiento de nuevas morales o nuevas religiones. Esa misma -llamada equivocadamente- maldad (Bosheit) se encuentra en los maestros y predicadores de lo "nuevo", pues lo desconocido es generalmente identificado con el "mal" porque conquista y pretende derrumbar lo antiguo; y sólo por esto, lo tradicional o aquello a lo que estamos acostumbrados se considera pues el "bien". En consecuencia, todos 1os impulsos e instintos son oportunos pues conservan la especie y son por esta razón indispensables, pero su función es distinta ${ }^{203}$.

Todo gran hombre (große Mensch) posee una fuerza retroactiva (rückwirkende Kraft), a partir de la cual puede revisar otra vez toda la Historia, descubrir secretos que aún guarda celosamente el pasado y reinterpretar nuevamente los relatos establecidos por la tradición ${ }^{204}$; todo gran hombre además, pertenece a una casta de individuos que sólo quieren "llegar a ser lo que son", es decir, los nuevos (die Neuen), los extraordinarios (die Einmaligen), los incomparables (die Unvergleichbaren), los que se legislan a sí mismos (die Sich-selber-Gesetzgebenden), los que se hacen a sí mismos (die Sich-selber-Schaffenden), los mejores aprendices y descubridores de la anarquía y necesidad del Universo; ellos son en otras palabras los físicos, los creadores ${ }^{205}$, los próximos educadores. 



\section{PARTE IV \\ Tercer período}

\section{Introito}

If that man should be lewdly given, he deceiveth me; for, Harry, I see virtue in his looks. If then the tree may be known by the fruit, as the fruit by the tree, then, peremptorily I speak it, there is virtue in that Falstaff. ${ }^{206}$

Para reflexionar y evitar los dolores, Nietzsche tiene que caminar aún más: lo hace entre seis y ocho horas diarias; y por las noches, necesita tomar hidrato de cloral para conciliar el sueño. La muerte de Wagner, un nuevo enemigo desde hace seis años, significa para el filósofo una auténtica liberación; y aún en estos años cree que sus antepasados son nobles polacos ${ }^{207}$. Ahora la travesía se desarrolla aproximadamente por los siguientes lugares: Leipzig, Basilea, Génova, Nervi, Santa Margherita, Rapallo, Zoagli, Roma, Alta Engadina, Naumburg, Niza, Venecia, Zürich, Menton, Toscana, Lago Mayor, Coira, y Turín. En esta ciudad a mediados de Septiembre de 1888, la salud se debilita notablemente; cesan las jaquecas, los vómitos y los dolores en general, con lo cual puede dedicarse al trabajo con nuevas energías. Pero los daños internos no desaparecen y Nietzsche pierde la sensibilidad, su capacidad de 
sentir dolor: es la calma que antecede a la tormenta. Este período se extiende hasta el 6 de Enero de 1889, fecha en que redacta su último escrito: una carta dirigida a Jacob Burckhardt. Tal vez pronto resulte necesario empezar a "contar desde un principio", pues "tot sind alle Götter, nun wollen wir, daß der Übermensch lebe" ${ }^{208}$. 


\section{Acápite 1: \\ Tentadores}

Los encargados de demostrar que el valor de las cosas "buenas" consiste en el hecho de estar emparentadas con las cosas "malas" -antitéticas en apariencia, pero tal vez idénticas entre sî ${ }^{209}$. son los integrantes de una nueva generación de filósofos, más precisamente, tentadores (Versucher) $^{210}$ filósofos del peligro (Philosophen des gefährlichen). En este sentido, suponer que la "noverdad" es condición para la vida significa oponerse peligrosamente a los sentimientos que fundan los valores tradicionales; y quien se atreve a esto se sitúa más allá del bien y del ma1 $1^{211}$, es decir, comienza a regirse por valores independientes de la moral vigente, con lo cual es capaz de adoptar una postura valorativa de carácter extramoral (außermoralische) ${ }^{212}$. Asimismo, estos nuevos filósofos no pueden tener dudas de que la mayor parte del pensar consciente está orientado por impulsos para discurrir por determinados senderos $^{213}$ y no otros; y saben además que todo instinto persigue dominar y por ello también filosofar ${ }^{214}$. 
En la vida sólo hay voluntad "fuerte" y voluntad "débil"215 y si la volición consiste básicamente en mandar y obedecer, el filósofo debe arrogarse el derecho de considerar la voluntad en sí misma desde el punto de vista de una moral en cuanto doctrina de las "relaciones de dominación",216. Por eso según Nietzsche, los auténticos filósofos legislan, establecen el "hacia dónde" y el "para qué" de la Humanidad; deben, por lo tanto, organizar la labor previa de los científicos y "obreros filosóficos" porque su conocimiento se transforma en "creación" y luego en "legislación", pues su "voluntad de verdad" es "voluntad de poder" $" 17$. 


\section{Acápite 2: \\ Aristocrático \& plebeyo}

Si admitimos la desigualdad entre las morales pues algunas son más elevadas que otras, no sólo aceptamos la desigualdad entre los hombres, sino también el orden jerárquico (Rangordnung) que se da en la Naturaleza. Por lo tanto, siguiendo a Nietzsche, exigir una moral igualitaria significa herir profundamente a los hombres que son superiores, pues lo justo para algunos no necesariamente resulta ser lo justo para otros ${ }^{218}$.

La elevación de la categoría Hombre ha sido hasta ahora y siempre será tarea de las sociedades aristocráticas, las cuales creen firmemente en una escala jerárquica de hombres de diferente valor entre sí. Además sin el "pathos de la distancia", tal como surge entre los distintos estamentos, no podría surgir el pathos del deseo de ampliar esa distancia y producir una diferencia espiritual, e incluso dentro del alma misma, para alcanzar estados más elevados y lograr de esta manera aquello que estamos buscando, esto es, la "Autosuperación del Hombre" (Selbst-Uberwindung des Menschen $)^{219}$. Toda cultura superior surge gracias a hombres dotados 
de una naturaleza plenamente poderosa, poseedores de una enorme fuerza de voluntad y ambición de grandeza, que deciden lanzarse sobre razas más débiles, aunque quizás más civilizadas y más pacificas.

La "casta aristocrática" siempre ha sido la casta de los bárbaros, la de la gran bestia rubia (blonde Bestie) ${ }^{220}$, cuya ventaja no consistió en la fuerza física, sino fundamentalmente en el poder de su psiquis; fueron hombres más completos o, como Nietzsche prefiere llamarlos, bestias más completas (ganzeren Bestien) ${ }^{221}$. Incluso, según Nietzsche, una aristocracia sana debe sentirse a sí misma como "sentido" y suprema justificación de la realeza y de la comunidad. Para esto, en la Historia de la Humanidad varios hombres fueron utilizados, sacrificados, disminuidos hasta convertirlos en hombres incompletos, en instrumentos o simplemente en esclavos, porque la sociedad no existía para sí misma, sino sólo como base sobre la cual una especie selecta de individuos podía dedicarse a sus tareas superiores y, en términos generales, a la elevación de su propio "ser" 222 .

Por ello para Nietzsche, las "diferentes morales" y los distintos valores surgen o bien en una clase dominante, consciente de sus diferencias frente a las clases dominadas, o bien entre los dominados, es decir, los esclavos. Cuando los dominadores son quienes establecen el concepto de "bueno", lo que distingue y determina los niveles de la jerarquía son los estados anímicos permanentemente elevados y orgullosos; en ese sentido, el hombre aristocrático "desprecia" a aquellos individuos cuyos estados anímicos son los contrarios. Así, en la moral de señores (HerrenMoral), los términos bueno (gut) y malo (schlecht) significan noble (vornehm) y despreciable (verächtlich), respectivamente. Los aristócratas desprecian al cobarde, al miedoso, al mezquino, al que piensa miserablemente en la utilidad de las cosas, al desconfiado, al que se rebaja a sí mismo, al adulador y principalmente, al mentiroso. 
Además, la clase aristocrática se siente "a sí misma" determinadora de los valores, pues ella representa la autoridad; por esto mismo, la máxima de su acción reza: "lo que me es perjudicial, es perjudicial en $s \hat{\imath}{ }^{, 223}$; y de esta manera puede conferir dignidad a todas las cosas. Ella es creadora de valores; y éste es en definitiva, el auténtico derecho señorial (Herrenrecht) ${ }^{224}$. Ella honra todo lo que posee y su moral es una forma de autoglorificación (Selbstverherrlichung). Por lo tanto, ella siempre es autorreferencial.

Entre los sentimientos que predominan en el hombre aristocrático se encuentran los siguientes: la plenitud, el poder y la riqueza desbordantes, el placer por la emoción violenta y del mismo modo, la capacidad de ayuda al desgraciado (pero no por compasión sino por un impulso causado por el exceso de su fuerza, que a su vez genera la autoadmiración del poder). Ello es obviamente, una manera de honrarse a sí mismo y de honrar de igual forma al que tiene poder sobre él.

Los valientes que así piensan, se encuentran muy alejados de aquella moral de esclavos que ve en la compasión, o en el obrar desinteresado, la mejor expresión de lo moral. También forma parte de la conducta moral aristocrática: la confianza en sí mismo, el orgullo de sí mismo y la hostilidad e ironía frente al désintéressement ${ }^{225}$. Los nobles saben que sólo frente a los pares se tienen deberes y frente a los plebeyos, los seres inferiores como dice Nietzsche, es lícito actuar "como el corazón quiere" 226 , como resulta evidente, más allá del bien y del mal. En consecuencia, la capacidad y el deber de sentir al mismo tiempo venganza y agradecimiento prolongados, la sutileza en las represalias, el refinamiento en las amistades, la necesidad de tener grandes y poderosos enemigos para canalizar los sentimientos de envidia, la belicosidad, la altivez, como la capacidad para ser buen amigo, son características básicas de la moral aristocrática; la cual, como está claro, no se funda en las "ideas modernas" ni en aquello que en la 
actualidad se entiende por "progreso". Finalmente y de acuerdo con la moral de señores, los hombres buenos inspiran y quieren inspirar temor, mientras que los malos son considerados hombres despreciables.

La moral de esclavos (Sklaven-Moral) es, en cambio, una moral de la utilidad; y aquí tiene su origen la contraposición entre bueno (gut) y malvado (böse). Los débiles y miserables consideran que el poder y lo peligroso forman parte del mal; por lo tanto, según la moral de esclavos los hombres buenos son por lo general "no peligrosos", bonachones, aunque también fáciles de estafar, un poco tontos, es decir, unos bonhommes ${ }^{227}$; mientras que los malvados son sencillamente, aquellos que inspiran un temor irracional.

Por otro lado, según Nietzsche, no podemos borrar del alma y el cuerpo de un hombre todas las características y legados de sus padres. En efecto, éste es el "problema de la raza"; si sabemos algo de los antepasados, es lícito sacar conclusiones acerca de los futuros descendientes. En tal caso, los rasgos definitorios que corresponden al auténtico tipo plebeyo (Pöbel-Typus) son: la fastidiosa incontinencia, la envidia mezquina y el grosero darse a sí mismo la razón. Porque todas las características perjudiciales de la sangre tienen que pasar minuciosa y necesariamente al hijo y, en la situación más favorable, la mejor cultura y la educación más refinada apenas pueden disfrazar momentáneamente la herencia recibida ${ }^{228}$.

De la misma manera, una nobleza de nacimiento o de sangre, y aquí Nietzsche no se refiere al derecho a usar la preposición "von", ante todo ennoblece al espíritu, pero una nobleza de espíritu no llega a ser suficiente para ennoblecer la sangre ${ }^{229}$. En cambio, para el alma aristocrática, el egoísmo entendido como la creencia en que a un noble tienen que estarle sometidos naturalmente otros seres, está basado en una ley fundamental del sentido común de las cosas; dicho en otras palabras, "ello es la justicia misma" existencia del orden jerárquico en la Naturaleza. Y para terminar, 
Nietzsche aclara que por otro lado, el rasgo esencial de un alma aristocrática consiste también en respaldar el respeto hacia sí misma $^{231}$.

En la antigüedad, los judíos comienzan la rebelión de esclavos en la moral (Sklavenaufstand in der Moral); ellos son quienes derriban e invierten con un odio desmedido, e ilimitado, la identificación aristocrática de los valores; con lo cual, la moral tradicional aceptada hasta ese preciso momento, sufre una transmutación radical. Desde entonces, los buenos son los miserables, los sufridos, los necesitados, los enfermos, los deformes, los piadosos, los elegidos de Dios; mientras que a los malos sólo les queda el lugar reservado para los agraciados físicamente, los nobles y los verdaderamente poderosos ${ }^{232}$. Y así paulatinamente triunfa la moral del hombre común. Todo se judaíza, se cristianiza, se vulgariza $^{233}$. Asimismo, mientras que la moral aristocrática parte de una magnífica autoafirmación, la moral de los esclavos ofrece un rotundo "no" a todo lo que es diferente de ella; y por lo tanto, su mejor propuesta creadora consiste fundamentalmente en un incorregible pero efectivo testimonio a partir de la negación ${ }^{234}$.

Los valores concernientes al "bien" y al "mal" se enfrentan desde hace miles de años en una encarnizada e implacable lucha cuya manifestación más evidente podemos observarla en la recordada oposición: "Roma contra Judea y Judea contra Roma". En este sentido y antes de la llegada del cristianismo, los romanos representan a los nobles, a los fuertes; mientras que los judíos, en opinión de Nietzsche, constituyen un pueblo sacerdotal guiado por una reacción originada en un profundo y milenario resentimiento ${ }^{235}$. 


\section{Acápite 3: Nihilismo}

La cultura europea se agita desde hace mucho tiempo a causa de una creciente presión, como si anunciara una catástrofe. Nietzsche narra la historia de aquello que para él constituyen los dos próximos siglos, es decir, los siglos XX y XXI: relata pues, la historia de "la irrupción del nihilismo" ${ }^{\text {236. }}$. Y es el estado transitorio en el que los valores supremos, considerados mandamientos divinos, realidades a cuyo servicio los hombres han dedicado toda su vida, pierden credibilidad cuando conocemos su demasiada humana procedencia; con lo cual, ya no hay ni "fin" ni "porqué" para continuar vigentes ${ }^{237}$. En este sentido, el "nihilismo radical" es la desvalorización absoluta $^{238}$. Por esta razón, en la concepción occidental del mundo acaece una desvalorización plena y creciente que hace que la vida carezca ya de sentido; y esto es, según Nietzsche, nuestro pesimismo o la preformación del nihilismo ${ }^{239}$.

El nihilismo como estado psicológico surge además cuando el Hombre, agotadas sus fuerzas y perdidas sus esperanzas, opta por abandonar la intensa búsqueda del sentido de todo lo que acontece. 
Asimismo, el nihilismo es el reconocimiento de un abundante derroche de energía, la frustración ante el "en vano" y la incertidumbre e imposibilidad de persistir en el intento. Planteado de esta manera, la causa del nihilismo es el desengaño ante un pretendido fin, cualquiera que éste haya sido, o de un devenir en el que nada se termina de realizar.

El nihilismo se manifiesta también cuando el Hombre, al lograr cierta estabilidad social, puede sistematizar u organizar su actividad diaria de modo que, ante la necesidad de respetar o venerar algo, se refugia en la esperanza de la existencia de un poder o gobierno superior en tanto "unidad", "totalidad" con forma de divinidad, fachada política, científica o estética que lo sobrepase ilimitadamente. Sin embargo, el origen de estas entidades obedece al deseo de dar crédito a sus propios valores, precisamente por haber perdido la fe en aquellos que desde la antigüedad se consideran divinos.

Y por último, el nihilismo se muestra en forma superlativa, al proclamar la negación del mundo metafísico, es decir, cuando el Hombre advierte que el ficticio mundo "verdadero" situado más allá, o detrás del mundo fenoménico, sólo se construye y sostiene para responder a necesidades humanas muy íntimas, con lo cual ya no puede aseverar su existencia en el sentido en el que siempre lo hizo. En tal caso, las categorías "causa", "fin", "unidad", etc., con las que valoramos el mundo son inevitablemente suprimidas y desde ese momento nuestra cosmovisión pierde todo su valor ${ }^{240}$. Lo antes expuesto arroja como resultado que la causa del nihilismo es la "creencia en las categorías de la razón"; pero fundamentalmente hay que centrar el problema, en primer lugar, en la falta de una especie superior (höhere Spezies), es decir, aquella capaz de mantener la creencia en el Hombre; y en segundo lugar, en la exageración por parte de una especie inferior (niedere Spezies) de haber convertido las necesidades humanas en valores metafísicos. Éste es el caso del 
gobierno del rebaño, de las masas y de la sociedad común, que no sólo vulgarizan la existencia, sino que también frustran y tiranizan al hombre excepcional ${ }^{241}$.

A modo de conclusión, Nietzsche observa que los valores de la Humanidad son instrumentos muy útiles, establecidos para mantener y aumentar los campos de dominio de los individuos pero luego son proyectados hacia las cosas ilícitamente a partir de una presupuesta esencia. El error consiste en que el Hombre se ha considerado él mismo como sentido y medida de todo aquello que lo rodea $^{242}$. Por eso, el nihilismo es el síntoma de un estado patológico "intermedio" en el que se atribuye realidad a las supuestas verdades absolutas ${ }^{243}$.

El nihilismo tiene también un doble sentido ${ }^{244}$, a saber: como "aumento de poder del espíritu", que se manifiesta a modo de fuerza violenta de destrucción, es decir, el llamado "nihilismo activo"; y como "decadencia y retroceso del poder del espíritu", esto es, el "nihilismo pasivo", cuya forma más célebre es el budismo que es en definitiva un "nihilismo fatigado"245. Bajo estas condiciones y en estas circunstancias, la decadencia es inevitable aunque es un proceso necesario por el cual hay que transitar para que resurja y se desarrolle nuevamente la vida ${ }^{246}$.

Nietzsche reconoce cuatro grandes períodos del nihilismo europeo. Al principio, un "período de obscuridad", en el que todas las clases protegen lo antiguo y al mismo tiempo promueven lo nuevo. Luego, un "período de claridad", en el que se comprende que los valores de la antigüedad, nacidos de la vida decadente y por ello contrarios a la vida, son antitéticos con los nuevos valores, nacidos de la vida ascendente. En este período se comprenden los ideales antiguos pero aún no se toleran los nuevos. Después, un "período de tres grandes afectos" en el que resaltan el desprecio, la compasión y la destrucción. Y por último, un "período de catástrofe" en el que 
asombrosamente aparece una desconocida y original doctrina que pone a prueba a todos los hombres sin excepción ${ }^{247}$.

En concreto, el nihilismo se manifiesta en las conclusiones sin sentido de las Ciencias Naturales; se observa en la Política; a través de la falta de confianza en el Derecho, cuando la inculpabilidad predomina en las sentencias como en el engaño y oportunismo reiterados; se muestra en la economía popular, con la supresión de la esclavitud y en la falta de una clase redentora y justificadora; se advierte en la Historia, con las concepciones fatalistas; y por ú1timo, aparece también en el Arte, precisamente en el romanticismo ${ }^{248}$. Por ello, el nihilismo es un cansancio, un estar hastiados de la categoría "Hombre" 249 porque significa para los sobrevivientes tener que enfrentarse a una última voluntad, y esto es, a la voluntad de "nada",250. 


\section{Acápite 4: Voluntad de poder}

Desde un principio, los individuos más poderosos son quienes asignan nombres a las cosas y posteriormente establecen las categorías $^{251}$. Así, la voluntad de verdad (Wille zur Wahrheit) es una tendencia que busca la estabilidad, la acción de hacer verdadero aquello que se presenta como permanente, la proyección de la verdad al ser o en otras palabras, la supresión de la falsedad. Por lo tanto, la verdad es construida y representa una labor minuciosa y sistemática; introducir la verdad es pues un proceso constante que encubre una voluntad de poder (Wille zur Macht $)^{252}$. En consecuencia, dice Nietzsche, todas las hipótesis sobre las cuales se construye una y otra vez el "mundo verdadero" tienen que ser corregidas; de lo contrario, si no se superan los prejuicios morales, el método científico no será riguroso, los resultados no serán exactos y la investigación como tal no cumplirá su función ${ }^{253}$.

La voluntad de poder es el deseo insaciable de mostrar o emplear poder a modo de impulso creador; todas las funciones de la vida orgánica, así como los instintos animales, pueden ser derivadas 
a partir de la voluntad de poder como de una única fuente ${ }^{254}$. En ese caso, el instinto de conservación sólo es la consecuencia de la voluntad de poder ${ }^{255}$; y lo mismo sucede con las acciones, las pasiones, la nutrición, la generación de la vida y el placer ${ }^{256}$. Todo acontecimiento en el Universo se reduce a la intención de aumentar el poder ${ }^{257}$; "fin", "meta" y "sentido" son modos de expresión y metamorfosis de una única voluntad de poder; por lo tanto, "querer" no es otra cosa que querer crecer, querer devenir más fuerte y querer tener los medios para lograrlo ${ }^{258}$. La voluntad de poder es entonces un pathos ${ }^{259}$; es el hecho fundamental del que resulta un devenir y un quehacer ${ }^{260}$.

La voluntad de poder de un cuerpo consiste en intentar adueñarse de todo el espacio circundante, extender la propia fuerza y rechazar todo aquello que se opone a su expansión; no obstante, es probable que choque con intentos semejantes de otros cuerpos y finalmente se ajuste, armonice y se unifique con los demás para conspirar en un proceso contínuo por el mantenimiento y la expansión de su poder ${ }^{261}$. La voluntad de poder se manifiesta en toda la Naturaleza en el instinto de defenderse del más fuerte y atacar al más débil ${ }^{262}$; sólo se muestra cuando encuentra resistencia y lo hace a modo de "apropiación" y "adición", esto es, como voluntad de usurpación, dominación y transformación hasta que el elemento sometido pasa al campo de fuerza del elemento atacante y le permite a este último aumentar su poder ${ }^{263}$.

La voluntad de poder, o dicho de otra manera, el "último fundamento y carácter de toda transformación" nos permite advertir, de acuerdo con Nietzsche, que la selección natural no se produce en favor de las excepciones o de los casos felices porque los más fuertes y afortunados, que constituyen una minoría, se muestran débiles cuando tienen en contra y se enfrentan a aquellos regidos por el instinto del rebaño, la pusilanimidad y la preponderancia numérica de los que componen la mayoría. En tal caso, predominan aquellos 
que comprometen el auténtico valor de la vida y hasta pueden ponerlo en peligro porque únicamente prevalecen los valores decadentes. Por lo tanto, hay que observar si la Naturaleza es cruel con los débiles y protectora de los fuertes como suele decirse o, si en cambio, es despiadada con los individuos excepcionales y permisiva con los mediocres, como afirma Nietzsche ${ }^{264}$.

Incluso, Nietzsche aclara que el concepto "dios" puede ser explicado mediante esta concepción como la cima del "poder" ("Macht"höhepunkt) ${ }^{265}$ o como el poder supremo (höchste Macht); en consecuencia, "de él se sigue todo, de él se sigue 'el mundo",266. Por consiguiente y para finalizar, lo "bueno" es todo aquello que aumenta el sentimiento de poder en el Hombre; lo "malo", en cambio es lo que proviene de la debilidad; y lo más perjudicial, según Nietzsche, obviamente el cristianismo debido a su apología de los débiles, los enfermos y desposeídos ${ }^{267}$. En definitiva, la vida es un impulso hacia el crecimiento, la apropiación y la acumulación y donde faltan estos atributos hay una evidente decadencia ${ }^{268}$. En pocas palabras, la vida misma es voluntad de poder $^{269}$. 


\section{Acápite 5: \\ Superhombre}

De la misma manera que con el correr de los milenios casi todos los seres originan algo mejor con respecto a ellos mismos y aunque la Humanidad, según Nietzsche, prefiera retornar a un estadio de serenidad e inocencia natural antes que autosuperarse, el hombre también tiene que ser superado. Si el mono es para el Hombre un motivo de risa, algo similar debe ser el Hombre para el superhombre (Übermensch); si en un principio el Hombre se asemejaba al simio, en la actualidad se le parece aún más; y si el científico, el especialista, en última instancia, no es más que un sinsentido, "el superhombre es el sentido de la tierra"270. El Hombre tiene que permanecer fiel a ese sentido, sin prestar atención a quienes hablan de abandonar la vida o de esperanzas en el más allá, porque de acuerdo con la visión de Nietzsche, son moribundos menospreciadores de una tierra que les resulta fatigosa.

Antiguamente, agrega Nietzsche, los crímenes contra Dios o mejor dicho, contra la Iglesia eran delitos imperdonables; pero Dios murió (starb), es decir, la Iglesia muere y con ello ya no hay lugar 
para tales crímenes. Hoy en cambio, la injuria más lamentable es la que se comete contra la tierra, contra la Naturaleza, esto es, cuando lo incognoscible es antepuesto al sentido de la tierra. Por lo tanto, lo mejor que puede sucederle al Hombre es que llegue "la hora del gran desprecio", en la que se hastíe de lo que hasta el presente ha entendido por "razón", "virtud", "felicidad", "justicia” y "compasión" animales irracionales y el superhombre, pero esto no debe ser entendido como una meta; por el contrario, consiste en un "tránsito" y en un "ocaso". Y mientras algunos todavía se sienten intensamente orgullosos con el estado de la cultura (Bildung) ${ }^{272}$, otros en cambio, viven para el desarrollo del auténtico conocimiento y para que pronto llegue el superhombre ${ }^{273}$.

Pero por ahora sólo habita el Hombre, el último Hombre (letzte Mensch): es decir, el que cuestiona constantemente y el que pretende empequeñecer al Universo con sus obstinadas aunque ciegas investigaciones. No obstante según Nietzsche, la transformación todavía es posible pero es preciso comenzar a trabajar antes de que sea demasiado tarde ${ }^{274}$.

$Y$ ya que la vida es ingrata, como misterioso su sentido, el Hombre necesita una orientación para su existencia y ella no puede ser otra que el advenimiento del superhombre ${ }^{275}$. Por lo tanto, hay que apartarse de las costumbres del rebaño, despreciar el bien y el mal en sentido tradicional y romper finalmente las tablas de valores del pasado para incorporar valores más adecuados, es decir, aquellos que demanda el mundo actual; y para esto último, Nietzsche piensa en la idea de "crear" 276 . Pero hay que hacerlo con "un santo decir $s \hat{\imath}$ "277, con la "soberbia del yo"278, con la nobleza requerida para crear algo nuevo y no, por el contario, con la bondad de los sacerdotes "predicadores de la muerte"279 que prefieren lo antiguo y tradicional ${ }^{280}$ a lo inédito y transgresor. Porque en definitiva, la sola posibilidad de superación del Hombre representa una esperanza 
basada en el pensamiento más sublime y, en consecuencia, no puede estar fundado sino en un verdadero amor a la vida ${ }^{281}$ que en última instancia es una constante autosuperación. Y esto, de acuerdo con Nietzsche, no puede ser otra cosa que la mismísima voluntad de $\operatorname{poder}^{282}$.

Por otro lado, el mundo gira en torno de los creadores ${ }^{283}$ porque son ellos quienes tienen el dominio de las palabras más poderosas, como es el caso de "bueno" y "malo". Luego y de manera coincidente, cada pueblo llega a expresar a través de sus propias tablas de valores su más íntima voluntad de poder ${ }^{284}$. Por esto mismo aclara Nietzsche, aquellos individuos "solitarios" de hoy serán en el futuro quienes conformarán un nuevo pueblo elegido y de él precisamente surgirá "el superhombre" ${ }^{285}$ que entre otras cosas podrá redefinir palabras tales como "voluptuosidad" (Wollust), "afán de dominio" (Herrschsucht) y "egoísmo" (Selbstsucht), quizás los conceptos más reprobados basta el presente ${ }^{286}$. Y además, el superhombre podrá descubrirse verdaderamente a sí mismo porque, a diferencia de aquellos agobiados por el "espíritu de la pesantez" que predican "bueno" y "malo" para todos por igual, él sabrá identificar cuáles son su propio bien y su propio mal ${ }^{287}$.

$\mathrm{Y}$ así desde un principio, también los representantes del espíritu de la pesantez crean la coacción y posteriormente el bien y el mal $^{288}$ porque de igual manera ellos, en su rol de creadores, saben establecer para su conveniencia qué es "bueno" y qué es "malo". Los creadores crean además la meta del Hombre y pueden fijar el sentido y futuro de la tierra ${ }^{289}$. En consecuencia, en lugar de aceptar ciegamente todo aquello que proviene de la autoridad, hay que aprender a decir "yo", "sí" y "no"290 porque las relaciones sociales deben cambiar, la civilización debe progresar, o en otras palabras, porque el Hombre puede, debe ser superado.

Debe surgir entonces una especie de hombres más fuertes, más elevados, cuyas características resulten ser distintas de las del 
tipo medio ${ }^{291}$ para que no sólo sean capaces de liberar una multiplicidad de impulsos tan abundante como únicamente ellos podrían soportar ${ }^{292}$, sino para que también puedan resistir las "más grandes responsabilidades" sin mostrar síntomas de desánimo o decaimiento ${ }^{293}$. Entonces, si aceptamos que el Hombre es un "noanimal" y a la vez un "superanimal", podemos admitir igualmente que el nuevo hombre superior es un "no-hombre" y del mismo modo un "superhombre" 294 , pues la superlativa elevación de la conciencia de fuerza (Größte Erhöhung des Kraftbewußtseins) en el Hombre es aquello que, en definitiva, crea las bases para el surgimiento del superhombre ${ }^{295}$. Y para concluir, no debemos olvidar según Nietzsche, que en este largo y complejo proceso el fin no es el progreso de la "Humanidad" sino, y por el contrario, el advenimiento del "superhombre",296.

"¿Llega a ser, el que eres!" 297 , reza la máxima; pero para 1legar a ser el que se es tenemos que partir del supuesto de no tener dudas acerca de lo que se es ${ }^{298}$. En consecuencia, dice Nietzsche, hay que comenzar por respetarse a sí mismo, amarse a sí mismo y ser absolutamente libre para consigo mismo ${ }^{299}$. Por ello, "superhombre" significa un tipo supremo de próspero bienestar (Typus höchster Wohlgeratenheit), algo muy distinto de aquello que definimos como hombres "modernos", "buenos", "cristianos" y "nihilistas"300. De esta manera, ser exigente y duro con uno mismo para luego poder serlo con los demás es el imperativo fundamental y el signo indiscutible de una "naturaleza dionisíaca". Porque “...todos los creadores son duros" ${ }^{\sharp 01}$, destructores, inmorales, transgresores y quebrantadores de los valores tradicionales; son todavía quienes promueven permanentemente la mayor violencia e incluso, y a riesgo de ser crucificados ${ }^{302}$, son también los más benefactores ${ }^{303}$. 
F.W. NIETZSCHE: Autosuperación del Hombre

"Lerntet ihr nun mein Lied? Errietet ihr, was es will? Wohlan! Wohlauf! Ihr höheren Menschen, so singt mir nun meinen Rundgesang!

Singt mir nun selber das Lied, des Name ist >Noch einmal , des Sinn ist >in alle Ewigkeit!! - singt, ihr höheren Menschen, Zarathustras Rundgesang!"

O Mensch! Gib acht!

Was spricht die tiefe Mitternacht?

"Ich schlief, ich schlief-,

Aus tiefem Traum bin ich erwacht: -

Die Welt ist tief,

Und tiefer als der Tag gedacht.

Tief ist ihr Weh-,

Lust - tiefer noch als Herzeleid:

Weh spricht: Vergeh!

Doch alle Lust will Ewigkeit-,

- will tiefe, tiefe Ewigkeit!" 304 



\section{EPÍLOGO \\ Ocaso}

\section{Introito}

Life's but a walking shadow, a poor player, That struts and frets his hour upon the stage, And then is heard no more; it is a tale Told by an idiot, full of sound and fury, Signifying nothing. ${ }^{305}$

Comienzan los famosos ataques "dionisíacos": Nietzsche está loco. De inmediato es trasladado desde Turín hacia Basilea y luego a Jena, lugares en donde recibe tratamiento médico. A partir de su internación, los primeros años son de cuidados intensivos pues representa cierto grado de peligrosidad pero con el correr del tiempo su salud mejora en parte. Después permanece en Naumburg atendido por su madre y posteriormente pasa sus últimos días en Weimar con "Lisbeth", su hermana. Llega a tener atisbos de conciencia; incluso puede decirse que recobra sus sentimientos, pero jamás vuelve a recuperar su genio creador. En definitiva, Friedrich Wilhelm Nietzsche sigue su propio camino ${ }^{306}$ y de acuerdo con esto, predica durante toda su vida: "Vademecum, vadetecum" $" 307$. 


\section{Acápite 1: \\ Hombre crepuscular}

Según Narciso Pousa ${ }^{308}$, Nietzsche no alude a una superación del concepto Hombre, sino a una "liberación" de las condiciones biológicas, económicas y espirituales que dificultan el desarrollo de la persona. La imprecisión de los caracteres de la imagen del Hombre sugiere la melancólica "esfuminatura" de lo crepuscular. El crepúsculo además constituye una "crisis". Es decir, cuando un período histórico en sentido hegeliano se acerca a su fin, el tiempo conlleva una crisis. Y entretanto el Hombre se apoya en la Historia y en su supuesto sentido sin reparar en el torbellino de sinsentido que lo rodea, 1o característico de la Humanidad crepuscular consiste en despertar a la "conciencia de nada". El estadio del hombre crepuscular es por lo tanto, el período de la "toma de conciencia". Consecuentemente, el tiempo de hoy es el tiempo del hombre crepuscular. Su imagen "...está constituida, no por aquellos rasgos que presenta, sino por los que ya no presenta, y los que todavía no presenta". Asimismo, el "crepúsculo de la Historia" coincide con la "muerte de Dios", con lo cual el Hombre debe "llenar" ese "vacío" 
con sus propias realizaciones. Y la "actitud crepuscular" consiste en la renuncia a toda pretensión de sentido; entonces el presente deja de ser comprensible para el sentido común. Sin duda, la imagen del crepúsculo significa igualmente el "momento auroral" hacia otro mediodía, pero también puede anunciar el amanecer de una nueva Humanidad.

El pensamiento de Nietzsche, pues, está en apariencias desarticulado como consecuencia de los permanentes dolores de vientre de un hombre que necesitaba caminar casi sin pausa para calmarlos. Por lo tanto, resulta necesario reconstruirlo a partir de sus aforismos como si fuera un gran espejo que se ha partido en mil pedazos y en el que Nietzsche siempre hubiera querido verse reflejado. Al final, y para aquellos que recorren su obra, aparece difusa la imagen del superhombre. En efecto; hay alguien que en verdad cambió la cultura y transmutó finalmente todos los valores establecidos. El superhombre aludido inició un movimiento formidable que perdura incólume hasta nuestros días. Posteriormente, sus seguidores emprendieron un camino del cual se escribieron, a favor y en contra, bibliotecas completas. Su nombre: Cristianismo; que, entre otras cosas, tuvo como propósito brindar máximas de acción para que cada uno de nosotros contribuyera a llevar adelante una auténtica y definitiva Autosuperación del Hombre.

\author{
¿Quién, si no tú \\ podía creer que algo descubría \\ al confirmar que el hombre ama el goce \\ $y$ ver la eternidad \\ como el portal ineludible? \\ ¿Acaso en el Filebo no debatió Platón \\ el valor del placer en la vida del hombre?
}


Ricardo Torres Medrano

La dulce alegría, la eternidad que se alza sobre el goce pasajero. La alegría es la que vuelve y vuelve en la vida del hombre convocando a tiempos postreros en que de nuevo regrese en la voz de los poetas servidores de Dios, y portavoces perfectos de un nuevo amanecer ${ }^{309}$. 


\section{ANEXOS}

\section{Nietzsche $^{310}$}

\section{Por Narciso Pousa}

\author{
El 3 de Enero de 1888, en Turín, \\ Nietzsche cayó sollozando y abrazado \\ a un caballo castigado por un cochero \\ en una vía pública de la ciudad, \\ fue el umbral de la locura.
}

Séptima soledad, antes del alba, por esas calles de Turín salías, viviendo la ciudad de los Saboya gente de mando en la feliz Italia. ¿Qué ilusión fatal con aquel Auriga del que Platón hablaba como rector del alma, entreviste en el fulmíneo rayo castigando al negro corcel de las pasiones? 
Ricardo Torres Medrano

Nadie lo sabrá jamás.

Pero tú caíste, sí, sollozando

presa de la piedad, del sentimiento

que tú aborrecías en los débiles

que seguimos a Cristo.

Desvarío final

amé el silencio claro

supe que tú, sí, llevaste la guerra

hasta el límite feroz de la fuerza.

Pero también me parece oír,

con voz gruesa de emperador apóstata,

esa frase final del sacrilegio

agónico y letal:

"Triunfaste, Galileo". 
F.W. NIETZSCHE: Autosuperación del Hombre

\section{Narciso Pousa $a^{311}$}

$(22 / 08 / 1920-28 / 10 / 2007)$

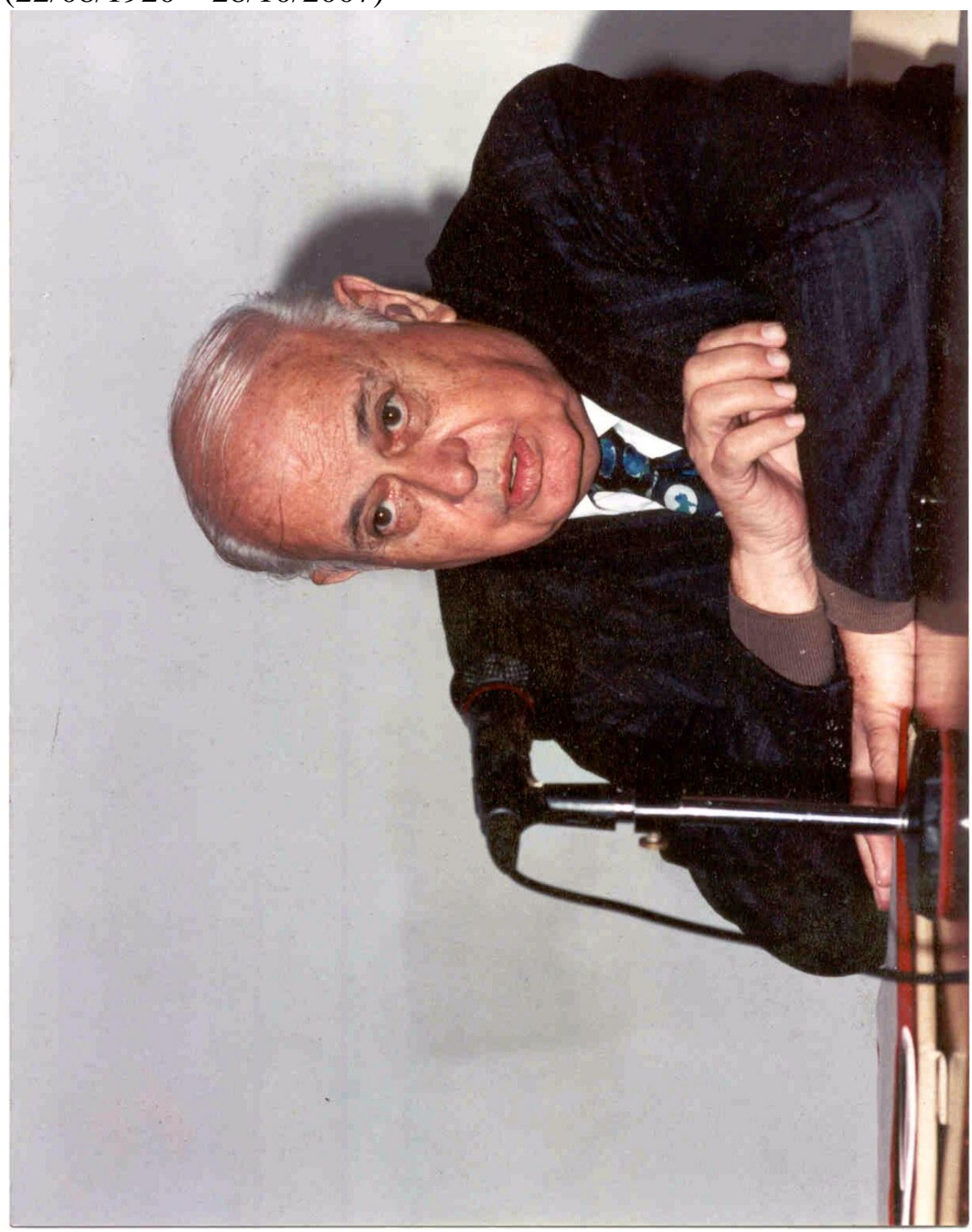





\section{NOTAS}

${ }^{1}$ Las dos primeras líneas se corresponden con el magistral "Responso a Verlaine" del vate máximo Darío, escrito a la muerte del poeta francés, maestro de su autor. N. de Atilio Milanta. Cfr.: MILANTA, Atilio (2012); Senza parole! iSin palabras!; La Plata; Dei Genitrix; p. 51.

2 "Contradicción en el adjetivo", es decir, una contradicción entre el sustantivo y el adjetivo complementario. N. del A.

3 Cfr.: SHAKESPEARE, William; Hamlet; Acto IV, Escena I en SHAKESPEARE, William. The Complete Works (1990). A new edition, edited with an introduction and glossary by Peter Alexander; London and Glasgow; Collins Clear-Type Press, en adelante SHAKESPEARE; p. 1057. "Y lo que es hecho inoportuno; la calumnia acaso- cuyo rumor desde un extremo al otro del mundo, con el nivel como el del cañón a su blanco, transporta su disparo envenenado- puede pasar por alto nuestro nombre, y golpear el aire invulnerable". T. del A.

${ }^{4}$ Cfr.: SHAKESPEARE; Hamlet; Acto III, escena I; p. 1047. “¿Quién podría tolerar tanta opresión, gruñir y sudar en una vida cansada, sino por el temor de algo después de la muerte- el país desconocido, de cuyos límites ningún caminante retorna- rompecabezas de la voluntad, y nos hace sufrir aquellos males que tenemos más que buscar otros que no conocemos?" T. del A.

${ }^{5}$ Cfr.: Menschliches, Allzumenschliches, en adelante MA, I, af. 483; en Nietzsche Studienausgabe in 4 Bänden, en adelanle Sag; AusgeWählt und eingeleitet von 
Hans Heinz Holz; Fischer Bücherei GmbH; Frankfurt am Main; 1968. Band 2. "Las convicciones son enemigas más peligrosas de la verdad que las mentiras". T. del A.

${ }^{6}$ Cfr.: SHAKESPEARE; The Second Part of King Henry the Fourth, Acto I, Escena II; p. 519. "La virtud es tan poco considerada en estos tiempos de vendedores ambulantes, que el verdadero valor se ha convertido en celda de osos. El embarazo es hecho tabernero y su vivo ingenio derrochado en extender cuentas; todos los otros dones que pertenecen al hombre, como la maldad de esta época les da forma, no valen una grosella". T. del A.

${ }^{7}$ Cfr.: Unzeitgemässe Betrachtungen en adelante UB, III, 4; en Nietzsches Werke in zwei Bänden, en adelanke NW; Herausgeber und Verfasser: Gerhard Stenzel; Verlag "Das Bergland-Buch"; Austria. Band II; p. 94.

${ }^{8}$ Cfr.: UB III, 6; en NW, Band II; p. 112.

${ }^{9}$ Cfr.: MA, I, af. 433 en Sag, Band 2; ps. 210 y 211.

${ }^{10}$ Cfr.: MA I, af. 520; en Sag, Band 2; p 234.

${ }^{11}$ Cfr.: Jenseits von Gut und Böse, en adelante JvGuB, af. 208; en Sag, Band 3; p. 111.

${ }^{12}$ Cfr.: Ecce Homo, en adelante EH; para "Götzendämmerung”, af. 1; en Sag, Band 4; p. 205.

${ }^{13}$ Cfr.: EH, para “Warum ich ein Schicksal bin”, af. 1; en Sag, Band 4; p. 212.

${ }^{14}$ Cfr.: JvGuB, af. 108; en Sag, Band 3; p. 78.

15 Cfr.: Götzen-Dämmerung en adelante GD, para "Die 'Verbesserer' der Menschheit", af. 1; en NW, Band II; p. 932.

${ }^{16}$ Cfr.: JvGuB, af. 188; en Sag, Band 3; p. 89.

${ }^{17}$ Cfr.: JvGuB, af. 48; en Sag, Band 3; p. 63.

${ }^{18}$ Cfr.: Der Antichrist, en adelante DA, af. 39; en Sag, Band 3; p. 210.

${ }^{19}$ Cfr.: Zur Genealogie der Moral, en adelante ZGdM, III, af. 27; en Sag, Band 4; p. 141.

${ }^{20}$ Cfr.: DA, af. 52; en Sag, Band 3; p. 225.

${ }^{21}$ Cfr.: DA, af. 48; en Sag, Band 3; p. 221.

${ }^{22}$ Cfr.: Nachgelassene Schriften, en adelante NS, II, af. 225; en NW, Band I; p. 847.

${ }^{23}$ Cfr.: EH, para "Die Unzeitgemäßen", af. 2; en Sag, Band 4; p. 184.

${ }^{24}$ Cfr.: EH, para "Also sprach Zarathustra", af. 5; en Sag, Band 4; p. 197.

${ }^{25}$ Cfr.: EH, para "Warun ich ein Schicksal bin", af. 2; en Sag, Band 4; p. 213.

${ }^{26}$ Cfr.: UB II, 6; en NW, Band II; p. 55.

${ }^{27}$ Cfr.: EH, para "Morgenröte", af. 2; en Sag, Band 4; p. 191.

${ }^{28}$ Cfr.: JvGuB, af. 295; en Sag, Band 3; p. 178. 
F.W. NIETZSCHE: Autosuperación del Hombre

${ }^{29}$ Cfr.: GD, para "Was ich den Alten verdanke", af. 5; en NW, Band II; p. 967.

${ }^{30}$ Cfr.: GD, para "Spüche und Pfeile", af. 15; en NW, Band II; p. 913.

${ }^{31}$ Cfr.: UB, III, 1; en NW, Band II. “... tus educadores no pueden ser más que tus liberadores".

${ }^{32}$ Cfr.: Also sprach Zarathustra, en adelante AsZ, III, Der Genesende, II; en NW, Band I. "Todo va, todo vuelve...". T. del A.

${ }^{33}$ Cfr.: AsZ, IV, Das Zeichen; en NW, Band I. “... mi hora llega”. T. del A.

${ }^{34}$ Cfr.: SHAKESPEARE; The Merchant of Venice, Acto III, Escena II; p. 238.

"El mundo está siendo engañado con el ornamento. ¿En el derecho, que causa tan viciada y corrupta pero, sazonada con una voz amable, oscurece el espectáculo del mal? ¿En la religión, el condenado error pero por alguna frente sobria bendecido y aprobado con un texto, oculta la grosería con ornamento de feria?" T. del A.

35 "Edad de la Obscuridad". T del A.

${ }^{36}$ Cfr.: UB II, 8; en Sag, Band 1; ps. 232-235.

${ }^{37}$ Cfr.: UB II, 9; en Sag, Band 1; ps. 239-241.

${ }^{38}$ Cfr.: UB III, 1; en NW, Band II; ps. 75-77.

${ }^{39}$ Cfr.: UB III, 3; en NW, Band II; ps. 87-90.

${ }^{40}$ Cfr.: MA I, af. 235; en Sag, Band 2; p. 149.

${ }^{41}$ Cfr.: MA I, af. 263; en Sag, Band 2; p. 164.

42 "Ocio". T. del A.

${ }^{43}$ Cfr.: MA I, af. 439; en Sag, Band 2; p. 209.

44 "Derecho de posesión". T. del A.

${ }^{45}$ Cfr.: MA I, afs. 452 y 446; en Sag, Band 2; ps. 214 y 211-212 respectivamente.

${ }^{46}$ Cfr.: MA I, af. 473; en Sag, Band 2; p. 224.

${ }^{47}$ Cfr.: MA I, af. 480; en Sag, Band 2; p. 228.

${ }^{48}$ Cfr.: MA I, af. 244; en Sag, Band 2; p. 154.

${ }^{49}$ Cfr.: Die fröhliche Wissenschaft, en adelante DfW, af. 269; en NW, Band II; p. 619.

${ }^{50}$ Cfr.: DfW, af. 149; en NW, Band II; p. 608.

${ }^{51}$ Cfr.: MA I, af. 463; en Sag, Band 2; p. 218. "Aplastad al infame”. T. del A.

${ }^{52}$ Cfr.: JvGuB, af. 38; en Sag, Band 3; p. 54.

${ }^{53}$ Cfr.: JvGuB, af. 46; en Sag, Band 3; p. 61.

${ }^{54}$ Cfr.: JvGuB, af. 195; en Sag, Band 3; p. 95.

${ }^{55}$ Cfr.: NS, I, af. 184; en NW, Band I; p. 755.

${ }^{56}$ Cfr.: JvGuB, af. 202; en Sag, Band 3; ps. 101 y 102.

${ }^{57}$ Cfr.: JvGuB, af. 203; en Sag, Band 3; p. 102.

${ }^{58}$ Cfr.: JvGuB, af. 242; en Sag, Band 3; ps. 139 y 140.

${ }^{59}$ Cfr.: JvGuB, af. 251; en Sag, Band 3; p. 148. 
${ }^{60}$ Cfr.: JvGuB, af. 43; en Sag, Band 3; p. 57.

${ }^{61}$ Cfr.: JvGuB, af. 212; en Sag, Band 3; p. 116.

62 "Derecho de sangre". T. del A.

${ }^{63}$ Cfr.: JvGuB, af. 213; en Sag, Band 3; p. 117.

${ }^{64}$ Cfr.: JvGuB, af. 227; en Sag, Band 3; p. 126.

${ }^{65}$ Cfr.: JvGuB, af. 262; en Sag, Band 3; ps. 162 y 163.

${ }^{66}$ Cfr.: JvGuB, af. 29; en Sag, Band 3; ps. 48 y 49.

${ }^{67}$ Cfr.: JvGuB, af. 268; en Sag, Band 3; ps. 166 y 167.

${ }^{68}$ Cfr.: JvGuB, af. 284; en Sag, Band 3; p. 173.

${ }^{69}$ Cfr.: ZGdM, II, af. 12; en Sag, Band 4; p. 75.

${ }^{70}$ Cfr.: NS, II, af. 309; en NW, Band I; p. 886.

${ }^{71}$ Cfr.: JvGuB, af. 259; en Sag, Band 3; ps. 156 y 157.

${ }^{72}$ Cfr.: SHAKESPEARE; The First Part of King Henry the Fourth, Acto V, Escena IV; p. 512. "Morir es ser una simulación; porque él es la simulación de un hombre que no tiene la vida de un hombre; pero la simulación de morir cuando un hombre vive, no es simulación, es la verdadera y perfecta imagen de la vida". T. del A.

73 "Pasión" o "emoción del alma". T. del A.

${ }^{74}$ Cfr.: Carta dirigida a su madre, fechada el 31 de Enero de 1866; en Friedrich Nietzsche, Werke und Briefe. Historisch-Kritische-Gesamtausgabe, en adelante HKG; C.H. Beck'sche Verlagsbuchhandlung; München; 1934. Briefe; Band 2; p. 32. "Primero vivir, después filosofar". T. del A.

${ }^{75}$ Cfr.: JANZ, Curt P. (1987); Friedrich Nietzsche; Madrid; Alianza. Volumen 1; ps. 23-27.

${ }^{76}$ Cfr.: Idem; ps. 27 y 28.

${ }^{77}$ Cfr.: Idem; ps. 30 y 31.

${ }^{78}$ Cfr.: "Fatum und Geschichte"; en HKG Werke, Band 2; p. 56.

${ }^{79}$ Cfr.: "Fatum und Geschichte"; en HKG Werke, Band 2; ps. 56 y 57. T. del A.

${ }^{80}$ Cfr.: "Fatum und Geschichte"; en HKG Werke, Band 2; p. 59. T. del A.

${ }^{81}$ Cfr.: "Fatum und Geschichte"; en HKG Werke, Band 2; p. 59. T. del A.

${ }^{82}$ Cfr.: "Willensfreiheit und Fatum" en HKG Werke, Band 2; ps. 60-62.

${ }^{83}$ Cfr.: "Willensfreiheit und Fatum" en HKG Werke, Band 2; p. 62.

${ }^{84}$ Cfr.: SHAKESPEARE; The Merchant of Venice, Acto II, Escena VII; p. 234. "Todo lo que reluce no es oro, a menudo Ud. ha oído este dicho; más de un hombre su vida ha vendido por contemplar mi exterior. Las tumbas doradas conservan los gusanos". T. del A.

${ }^{85}$ Cfr.: "Homer und die Klassische Philologie"; en HKG Werke, Band 5; p. 305. "Filosofía de hecho es lo que fue filología". T. del A. 
F.W. NIETZSCHE: Autosuperación del Hombre

${ }^{86}$ Cfr.: "Versuch einer Selbstkritik", 3; en NW, Band I; p. 596.

${ }^{87}$ Cfr.: "Versuch einer Selbstkritik", 3; en NW, Band I; p. 600.

${ }^{88}$ Cfr.: Die Geburt der Tragödie, en adelante DGdT, 1; en Sag, Band 1; p. 31.

${ }^{89}$ Cfr.: DGdT, 1; en Sag, Band 1; p. 31.

${ }^{90}$ Cfr.: DGdT, 1; en Sag, Band 1; p. 32.

${ }^{91}$ Cfr.: DGdT, 1; en Sag, Band 1; p. 33.

${ }^{92}$ Cfr.: DGdT, 1; en Sag, Band 1; p. 34.

${ }^{93}$ Cfr.: DGdT, 1; en Sag, Band 1; p. 34.

${ }^{94}$ Cfr.: DGdT, 1; en Sag, Band 1; p. 34.

${ }^{95}$ Cfr.: DGdT, 2; en Sag, Band 1; p. 34.

${ }^{96}$ Cfr.: DGdT, 7; en Sag, Band 1; ps. 53 y 54.

${ }^{97}$ Cfr.: DGdT, 10; en Sag, Band 1; p. 64.

${ }^{98}$ Cfr.: DGdT, 12; en Sag, Band 1; p. 72.

${ }^{99}$ Cfr.: DGdT, 12; en Sag, Band 1; ps. 73 y 74.

${ }^{100}$ Cfr.: DGdT, 13; en Sag, Band 1; p. 77.

${ }^{101}$ Cfr.: DGdT, 13; en Sag, Band 1; p. 78.

${ }^{102}$ Cfr.: DGdT, 13; en Sag, Band 1; p. 78.

${ }^{103}$ Cfr.: DGdT, 14; en Sag, Band 1; ps. 80-82.

${ }^{104}$ Cfr.: DGdT, 15; en Sag, Band 1; ps. 83 y 84.

${ }^{105}$ Cfr.: DGdT, 15; en Sag, Band 1; p. 85.

${ }^{106}$ Cfr.: DGdT, 17; en Sag, Band 1; ps. 92 y 93.

${ }^{107}$ Cfr.: DGdT, 15; en Sag, Band 1; ps. 85 y 86.

${ }^{108}$ Cfr.: DGdT, 17; en Sag, Band 1; ps. 95 y 96.

${ }^{109}$ Cfr.: DGdT, 18; en Sag, Band 1; p. 96.

${ }^{110}$ Cfr.: DGdT, 18; en Sag, Band 1; ps. 97 y 98.

${ }^{111}$ Cfr.: DGdT, 19; en Sag, Band 1; ps. 104 y 105.

${ }^{112}$ Cfr.: DGdT, 20; en Sag, Band 1; p. 108.

${ }^{113}$ Cfr.: DGdT, 23; en Sag, Band 1; ps. 119 y 120.

${ }^{114}$ Cfr.: DGdT, 16; en Sag, Band 1; p. 90.

${ }^{115}$ Cfr.: DGdT, 21; en Sag, Band 1; ps. 109 y 110.

${ }^{116}$ Cfr.: DGdT, 22; en Sag, Band 1; p. 114.

${ }^{117}$ Cfr.: DGdT, 23; en Sag, Band 1; p. 117.

${ }^{118}$ Cfr.: DGdT, 24; en Sag, Band 1; p. 122.

${ }^{119}$ Cfr.: DGdT, 25; en Sag, Band 1; p. 124.

${ }^{120}$ Cfr.: DGdT, 24; en Sag, Band 1; ps. 123 y 124.

${ }^{121}$ Cfr.: UB I, 1; en NW, Band II. ps. 11 y 12.

${ }^{122}$ Cfr.: UB I, 2; en NW, Band II. ps. 12 y 13.

${ }^{123}$ Cfr.: UB I, 9-11; en NW, Band II. p. 28. 
${ }^{124}$ Cfr.: UB II, 5; en Sag, Band 1; ps. 212 y 213.

125 "Verdad Eterna". T. del A.

${ }^{126}$ Cfr.: UB II, 10; en Sag, Band 1; ps. 245-247.

${ }^{127}$ Cfr.: UB III, 1; en NW, Band II; p. 78.

${ }^{128}$ Cfr.: UB II, 10; en Sag, Band 1; ps. 248 y 249.

${ }^{129}$ Cfr.: UB II, 10; en Sag, Band 1; p. 247.

${ }^{130}$ Cfr.: UB II, 10; en Sag, Band 1; ps. 248 y 249.

${ }^{131}$ Cfr.: UB II, 10; en Sag, Band 1; ps. 249 y 250.

${ }^{132}$ Cfr.: UB II, 10 y 2; en Sag, Band 1; ps. 250 y 196-201 respectivamente.

${ }^{133}$ Cfr.: UB II, 10; en Sag, Band 1; p. 251.

${ }^{134}$ Las otras dos imágenes corresponden al hombre de Rousseau y al hombre de Goethe. Cfr.: UB III, 4; en NW, Band II. p. 95.

${ }^{135}$ Cfr.: UB III, 4; en NW, Band II; ps. 96 y 97.

${ }^{136}$ Cfr.: UB III, 4; en NW, Band II; p. 97.

${ }^{137}$ Cfr.: UB III, 4; en NW, Band II; p. 97.

${ }^{138}$ Cfr.: UB III, 4; en NW, Band II; p. 98.

${ }^{139}$ Cfr.: UB III, 5; en NW, Band II; p. 100.

${ }^{140}$ Cfr.: UB III, 5; en NW, Band II; ps. 100-102.

${ }^{141}$ Cfr.: UB III, 5; en NW, Band II; p. 102.

${ }^{142}$ Cfr.: UB III, 6; en NW, Band II; p. 104.

${ }^{143}$ Cfr.: UB III, 6; en NW, Band II; ps. 104 y 105.

${ }^{144}$ Cfr.: UB III, 6; en NW, Band II; ps. 111 y 112.

145 SHAKESPEARE; Macbeth, Acto II, Escena II; ps. 1006 y 1007. "Uno gritó ‘Dios nos bendiga!' y el otro 'iAmén!', como si me hubieran visto con estas manos de verdugo. Oyendo su espanto, no pude decir 'Amén' cuando ellos dijeron ‘Dios nos bendiga!"”. T. del A.

${ }^{146}$ Cfr.: MA I, af. 630; en Sag, Band 2; p. 256. "Creo porque es absurdo". T. del A.

${ }^{147}$ Cfr.: MA I, af. 2; en Sag, Band 2; ps. 31 y 32.

${ }^{148}$ Cfr.: MA I, af. 3; en Sag, Band 2; ps. 32 y 33.

${ }^{149}$ Cfr.: MA I, af. 11; en Sag, Band 2; ps. 35 y 36.

${ }^{150}$ Cfr.: MA I, af. 16; en Sag, Band 2; ps. 39-41.

${ }^{151}$ Cfr.: MA I, af. 22; en Sag, Band 2; p. 44.

${ }^{152}$ Cfr.: MA I, afs. 23 y 24; en Sag, Band 2; ps. 45 y 46.

${ }^{153}$ Cfr.: MA I, af. 25; en Sag, Band 2; p. 46.

${ }^{154}$ Cfr.: MA I, af. 26; en Sag, Band 2; p. 47.

${ }^{155}$ Cfr.: MA I, af. 244; en Sag, Band 2; p. 154.

${ }^{156}$ Cfr.: MA I, af. 578; en Sag, Band 2; p. 242. 
F.W. NIETZSCHE: Autosuperación del Hombre

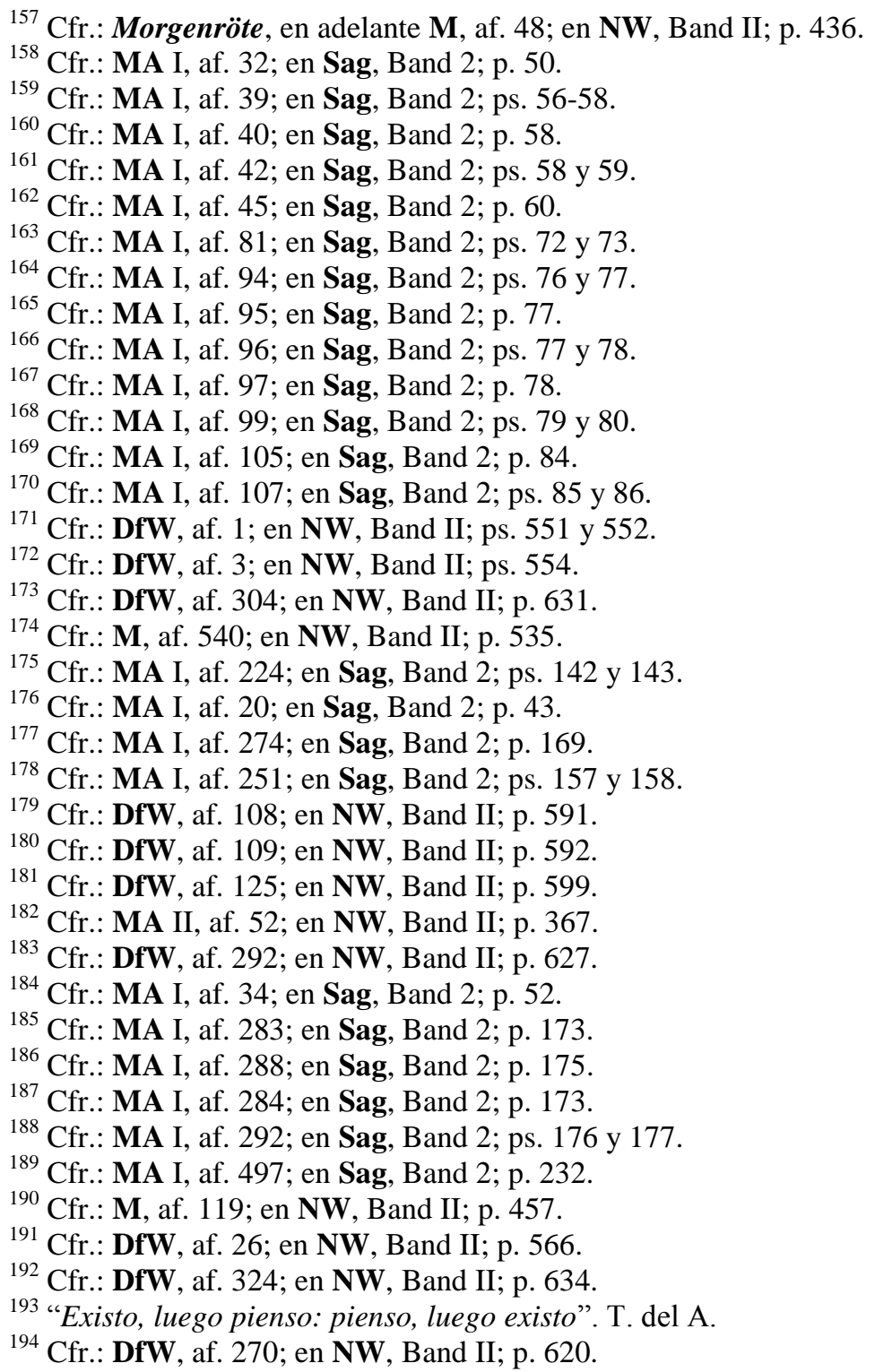


${ }^{195}$ Cfr.: DfW, af. 283; en NW, Band II; p. 624.

${ }^{196}$ Cfr.: MA I, af. 225; en Sag, Band 2; p. 144.

${ }^{197}$ Cfr.: MA I, af. 230; en Sag, Band 2; p. 146.

${ }^{198}$ Cfr.: MA I, af. 291; en Sag, Band 2; ps. 175 y 176.

${ }^{199}$ Cfr.: MA I, af. 427; en Sag, Band 2; p. 205.

${ }^{200}$ Cfr.: MA II, af. 11; en NW, Band II; p. 278.

${ }^{201}$ Cfr.: MA II, af. 336; en NW, Band II; p. 343.

${ }^{202}$ Cfr.: MA II, af. 182; en NW, Band II; p. 389.

${ }^{203}$ Cfr.: DfW, af. 4; en NW, Band II; p. 555.

${ }^{204}$ Cfr.: DfW, af. 34; en NW, Band II; ps. 567 y 568.

${ }^{205}$ Cfr.: DfW, af. 335; en NW, Band II; ps. 640 y 641.

${ }^{206}$ Cfr.: SHAKESPEARE; The First Part of King Henry the Fourth, Acto II, Escena IV; p. 495. "Si ese hombre fuera un libertino, me decepcionaría, porque, Enrique, veo virtud en su mirar. Sí entonces el árbol puede ser conocido por el fruto, como el fruto por el árbol, entonces perentoriamente yo declaro que, hay virtud en ese Falstaff". T. del A.

${ }^{207}$ Cfr.: EH, para "Warum ich so weise bin", af. 3; en Sag, Band 4; p. 149.

${ }^{208}$ Cfr.: AsZ, I; en NW, Band I; p. 366. "Todos los dioses están muertos, ahora queremos que viva el superhombre". T. del A.

${ }^{209}$ Cfr.: JvGuB, af. 2; en Sag, Band 3; p. 28.

${ }^{210}$ Cfr.: JvGuB, af. 42; en Sag, Band 3; p. 57.

${ }^{211}$ Cfr.: JvGuB, af. 4; en Sag, Band 3; p. 29.

${ }^{212}$ Cfr.: JvGuB, af. 32; en Sag, Band 3; p. 51.

${ }^{213}$ Cfr.: JvGuB, af. 3; en Sag, Band 3; p. 28.

${ }^{214}$ Cfr.: JvGuB, af. 6; en Sag, Band 3; p. 30.

${ }^{215}$ Cfr.: JvGuB, af. 21; en Sag, Band 3; p. 41.

${ }^{216}$ Cfr.: JvGuB, af. 19; en Sag, Band 3; p. 40.

${ }^{217}$ Cfr.: JvGuB, af. 211; en Sag, Band 3; ps. 114 y 115.

${ }^{218}$ Cfr.: JvGuB, af. 228; en Sag, Band 3; p. 127.

${ }^{219}$ Cfr.: JvGuB, af. 257; en Sag, Band 3; ps. 154 y 155.

${ }^{220}$ Cfr.: ZGdM, I, af. 11; en Sag, Band 4; p. 47.

${ }^{221}$ Cfr.: JvGuB, af. 257; en Sag, Band 3; ps. 154 y 155.

${ }^{222}$ Cfr.: JvGuB, af. 258; en Sag, Band 3; ps. 155 y 156.

${ }^{223}$ Cfr.: JvGuB, af. 260; en Sag, Band 3; ps. 157-159.

${ }^{224}$ Cfr.: JvGuB, af. 261; en Sag, Band 3; p. 160.

225 "Desinterés". T. del A.

${ }^{226}$ Cfr.: JvGuB, af. 260; en Sag, Band 3; p. 158.

227 "Bueno; amable; altruista". T. del A. 


\footnotetext{
${ }^{228}$ Cfr.: JvGuB, af. 264; en Sag, Band 3; p. 164.

${ }^{229}$ Cfr.: NS, IV, af. 203; en NW, Band I; p. 1056.

${ }^{230}$ Cfr.: JvGuB, af. 265; en Sag, Band 3; p. 165.

${ }^{231}$ Cfr.: JvGuB, af. 287; en Sag, Band 3; p. 174.

${ }^{232}$ Cfr.: ZGdM, I, af. 7; en Sag, Band 4; ps. 41 y 42.

${ }^{233}$ Cfr.: ZGdM, I, af. 9; en Sag, Band 4; p. 43.

${ }^{234}$ Cfr.: ZGdM, I, af. 10; en Sag, Band 4; p. 44.

${ }^{235}$ Cfr.: ZGdM, I, af. 16; en Sag, Band 4; ps. 54 y 55.

${ }^{236}$ Cfr.: NS, III, af. 79; en NW, Band I; p. 908.

${ }^{237}$ Cfr.: NS, III, af. 92; en NW, Band I; p. 914.

${ }^{238}$ Cfr.: NS, III, af. 96; en NW, Band I; p. 916.

${ }^{239}$ Cfr.: NS, III, af. 81; en NW, Band I; p. 910.

${ }^{240}$ Cfr.: NS, III, af. 103 A; en NW, Band I; ps. 919 y 920.

${ }^{241}$ Cfr.: NS, III, af. 93; en NW, Band I; ps. 914 y 915.

${ }^{242}$ Cfr.: NS, III, af. 103 B; en NW, Band I; p. 921.

${ }^{243}$ Cfr.: NS, III, af. 105; en NW, Band I; ps. 921 y 922.

${ }^{244}$ Cfr.: NS, III, af. 143; en NW, Band I; ps. 931 y 932.

${ }^{245}$ Cfr.: NS, III, af. 146; en NW, Band I; p. 933.

${ }^{246}$ Cfr.: NS, III, af. 87; en NW, Band I; p. 912.

${ }^{247}$ Cfr.: NS, III, af. 80 a; en NW, Band I; p. 910.

${ }^{248}$ Cfr.: NS, III, af. 94; en NW, Band I; p. 915.

${ }^{249}$ Cfr.: ZGdM, I, af. 12; en Sag, Band 4; p. 49.

${ }^{250}$ Cfr.: ZGdM, III, af. 14; en Sag, Band 4; p. 111.

${ }^{251}$ Cfr.: NS, I, af. 97 a; en NW, Band I; p. 719.

${ }^{252}$ Cfr.: NS, II, af. 228; en NW, Band I; p. 849.

${ }^{253}$ Cfr.: NS, I, af. 99; en NW, Band I; p. 720.

${ }^{254}$ Cfr.: NS, II, af. 229; en NW, Band I; p. 849.

${ }^{255}$ Cfr.: NS, II, af. 173; en NW, Band I; p. 826.

${ }^{256}$ Cfr.: NS, II, af. 169; en NW, Band I; p. 825.

${ }^{257}$ Cfr.: NS, II, af. 244; en NW, Band I; p. 855.

${ }^{258}$ Cfr.: NS, II, af. 245; en NW, Band I; p. 855.

259 "Apelar a los sentimientos; apasionamiento". T. de A.

${ }^{260}$ Cfr.: NS, II, af. 242; en NW, Band I; p. 854.

${ }^{261}$ Cfr.: NS, II, af. 241; en NW, Band I; p. 853.

${ }^{262}$ Cfr.: NS, II, af. 174; en NW, Band I; p. 826.

${ }^{263}$ Cfr.: NS, II, af. 171; en NW, Band I; p. 825.

${ }^{264}$ Cfr.: NS, I, af. 234; en NW, Band I; ps. 774-776.

${ }^{265}$ Cfr.: NS, II, af. 198; en NW, Band I; p. 835.
} 
Cfr.: NS, IV, af. 436; en NW, Band I; p. 1131.

${ }^{267}$ Cfr.: DA, af. 2; en Sag, Band 3; p. 181.

${ }^{268}$ Cfr.: DA, af. 6; en Sag, Band 3; p. 183.

${ }^{269}$ Cfr.: JvGuB, af. 259; en Sag, Band 3; p. 156.

${ }^{270}$ Cfr.: AsZ, I; en NW, Band I; p. 306.

${ }^{271}$ Cfr.: AsZ, I; en NW, Band I; p. 305-307.

${ }^{272}$ Cfr.: AsZ, I; en NW, Band I; p. 309.

${ }^{273}$ Cfr.: AsZ, I; en NW, Band I; p. 308.

${ }^{274}$ Cfr.: AsZ, I; en NW, Band I; ps. 309 y 310.

${ }^{275}$ Cfr.: AsZ, I; en NW, Band I; p. 312.

${ }^{276}$ Cfr.: AsZ, I; en NW, Band I; p. 315.

${ }^{277}$ Cfr.: AsZ, I; en NW, Band I; p. 320.

${ }^{278}$ Cfr.: AsZ, I; en NW, Band I; p. 325.

${ }^{279}$ Cfr.: AsZ, I; en NW, Band I; ps. 335-337.

${ }^{280}$ Cfr.: AsZ, I; en NW, Band I; p. 335.

${ }^{281}$ Cfr.: AsZ, I; en NW, Band I; p. 339.

${ }^{282}$ Cfr.: AsZ, II; en NW, Band I; p. 398.

${ }^{283}$ Cfr.: AsZ, I; en NW, Band I; p. 342.

${ }^{284}$ Cfr.: AsZ, I; en NW, Band I; ps. 347 y 348.

${ }^{285}$ Cfr.: AsZ, I; en NW, Band I; p. 364.

${ }^{286}$ Cfr.: AsZ, III; en NW, Band I; ps. 463-466.

${ }^{287}$ Cfr.: AsZ, III; en NW, Band I; ps. 466-470.

${ }^{288}$ Cfr.: AsZ, III; en NW, Band I; p. 472.

${ }^{289}$ Cfr.: AsZ, III; en NW, Band I; p. 471.

${ }^{290}$ Cfr.: AsZ, III; en NW, Band I; p. 469.

${ }^{291}$ Cfr.: NS, IV, af. 339; en NW, Band I; p. 1092.

${ }^{292}$ Cfr.: NS, IV, af. 326; en NW, Band I; ps. 1087 y 1088.

${ }^{293}$ Cfr.: NS, IV, af. 291; en NW, Band I; p. 1080.

${ }^{294}$ Cfr.: NS, IV, af. 368; en NW, Band I; p. 1103.

${ }^{295}$ Cfr.: NS, IV, af. 161; en NW, Band I; p. 1048.

${ }^{296}$ Cfr.: NS, IV, af. 170; en NW, Band I; p. 1050.

${ }^{297}$ Cfr.: AsZ, IV; en NW, Band I; p. 509.

${ }^{298}$ Cfr.: EH, para "Warum ich so klug bin", af. 9; en Sag, Band 4; p. 167.

${ }^{299}$ Cfr.: DA, Vorwort; en Sag, Band 3; p. 180.

${ }^{300}$ Cfr.: EH, para "Warum ich so gute Bücher schreibe", af. 1; en Sag, Band 4; p. 171.

${ }^{301}$ Cfr.: EH, para “Also sprach Zarathustra”, af. 8; en Sag, Band 4; p. 203.

${ }^{302}$ Cfr.: EH, para "Warum ich ein Schicksal bin", af. 4; en Sag, Band 4; p. 214. 
F.W. NIETZSCHE: Autosuperación del Hombre

${ }^{303}$ Cfr.: EH, para "Warum ich ein Schicksal bin", af. 2; en Sag, Band 4; ps. 212 y 213.

${ }^{304}$ Cfr.: AsZ, IV, Das trunkne Lied, XII; en NW, Band I. “ ¿Han aprendido ahora mi canción? ¿Han adivinado lo que quiere? ¡Bueno! ¡Levántense! ¡Vosotros hombres superiores, así canten ahora mi canto de ronda! Canten ahora vosotros la canción, el nombre es "una vez más", el significado es "por toda la eternidad" canten, vosotros hombres superiores, el canto de ronda de Zarathustra!".

¡Oh hombre! ¡Cuidado!

¿Qué dice la profunda medianoche?

"Yo dormí, yo dormí -,

Del sueño profundo me desperté: -

El mundo es profundo,

y más profundo de lo que pensaba el día.

Profundo es su infortunio -,

Placer - aún más profundo que el dolor puede ser:

¡El dolor dice: pasa!

Pero todo placer quiere eternidad -

- ¿Quiere profunda, profunda eternidad”!

T. del A.

305 SHAKESPEARE; Macbeth, Acto V, Escena V; ps 1024 y 1025. "La vida es una sombra caminante, un pobre actor, que se pavonea y agita su hora sobre el escenario y luego se oye nada más; es un cuento narrado por un idiota, lleno de ruido y furia, significando nada". T. del A.

${ }^{306}$ Cfr.: UB III, 1; en NW, Band II; p. 77.

${ }^{307}$ Cfr.:Gedichte und Sprüche; para "Scherz, List und Rache", 7; en NW, Band I; p. 228. "Ven conmigo, ve contigo; si me sigues, síguete a tí mismo". T. del A.

${ }^{308}$ Cfr.: POUSA, Narciso (1967); "El hombre crepuscular"; La Plata; Separata de la Revista de Filosofía de la Universidad Nacional de La Plata - Facultad de Humanidades y Ciencias de la Educación - Departamento de Filosofía - Instituto de Filosofía. Número 18.

309 Cfr.: POUSA, Narciso (1999); Poesía (1939 - 1999); La Plata; Almenara. "ZARATUSTRA"; p. 257.

${ }^{310}$ Cfr.: Idem; p. 258.

311 Fotografía tomada el día 23 de Noviembre de 2002 con motivo de la conferencia "El Acto Espiritual" dictada por el Prof. Narciso Pousa en LA PROTECTORA, Sociedad de Socorros Mutuos y actividades Sociales y Culturales, fundada en 1890 y ubicada en la Calle 49 N $^{\circ} 674$, entre 8 y 9 de la ciudad de La Plata, Buenos Aires. 